\title{
Review
}

\section{The immune-nutrition interplay in aging - facts and controversies}

\author{
Iftikhar Alam, a,b,c,*, Ali M. Almajwal ${ }^{\mathrm{a}, *}$, Wajid Alam ${ }^{\mathrm{d}}$, Ibrar Alame, Niamat Ullah ${ }^{\mathrm{f}}$, \\ Mahmoud Abulmeaaty ${ }^{\mathrm{a}}$, Suhail Razak ${ }^{\mathrm{a}}$, Saleem Khan ${ }^{\mathrm{f}}$, Graham Pawelec ${ }^{\mathrm{c}, \mathrm{g}, \mathrm{h}}$ \\ and Parvez Iqbal Paracha ${ }^{\mathrm{f}}$ \\ ${ }^{a}$ Department of Community Health Sciences, Clinical Nutrition Program, \\ College of Applied Medical Sciences, King Saud University, Riyadh, Saudi Arabia \\ ${ }^{\mathrm{b}}$ Department of Human Nutrition \& Dietetics, Bacha Khan University Charsadda, \\ Charsadda, Khyber Pakhtunkhwa, Pakistan \\ ${ }^{\mathrm{c}}$ Tübingen Ageing and Tumour Immunology Group, Zentrum für Medizinische Forschung, \\ University of Tübingen, Tübingen, Germany \\ ${ }^{\mathrm{d}}$ Oral and Maxillofacial Surgery, Khyber Colleg of Dentistry, KPK, Peshawar, Pakistan \\ ${ }^{\mathrm{e}}$ Department of Biotechnology, Bacha Khan University Charsadda, Charsadda, \\ Khyber Pakhtunkhwa, Pakistan \\ ${ }^{\mathrm{f}}$ Department of Human Nutrition, The Agriculture University Peshawar, \\ Khyber Pakhtunkhwa, Pakistan \\ ${ }^{\mathrm{g}}$ Health Sciences North Research Institute, Sudbury, ON, Canada \\ ${ }^{\mathrm{h}}$ John van Geest Cancer Research Centre, Nottingham Trent University, \\ Nottingham, UK
}

\begin{abstract}
Nutrition influences immunity in multiple ways, with different nutrients affecting many immune parameters. Aging also affects immunity, making the outcome of the interplay between nutrition, age and immunity complex. Moreover, a particular nutrient may alter the whole immune constellation as deficiency of one nutrient may affect the proper metabolism of another nutrient and elicit a chain reaction of secondary malnutrition. In this article, we review these interactions and the possible mechanisms mediating such relationships.
\end{abstract}

Keywords: Nutrition, immunity, immunocompetence, T cells, aging, aging nutrimmunity

\section{List of abbreviations}

$\begin{array}{ll}\text { APC } & \text { Antigen Presenting Cells } \\ \text { BMI } & \text { Body Mass Index } \\ \text { BMR } & \text { Basal Metabolic Rate } \\ \text { CM } & \text { Central Memory } \\ \text { CMV } & \text { Cytomegalovirus } \\ \text { CR } & \text { Caloric Restriction } \\ \text { CRP } & \text { C-reactive protein }\end{array}$

${ }^{*}$ Corresponding authors: Iftikhar Alam, $\mathrm{PhD}$ (rer nat) E-mail: ialam@ksu.edu.sas and Ali M. Almajwal, PhD, Department of Community Health Sciences, Clinical Nutrition Program, College of Applied Medical Sciences, King Saud University, Riyadh, Saudi Arabia. E-mail: aalmajwal123@yahoo.com.
DTH Delayed-Type Hypersensitivity

GM-CSF Granulocyte colony-stimulating factor

IL-1RI Interleukin 1 receptor, type

I IL-6 Interleukin-6

LBM Lean Body Mass

IRP Immune Risk Profile

mTOR Mammalian target of Rapamycin

MAIT Mucosal-associated invariant T

$\mathrm{MCH}$ Major Histocompatibility Complex

NK Natural Killer

PEM Protein Energy Malnutrition

TCR T-cell receptor

WEIRD White, Educated, Industrialized, Rich and Democratic 


\section{Introduction}

It is well-known that underprivileged people with compromised nutritional status suffer a higher risk of infection [1-3]. However, knowledge of the role that particular nutrients play and the mechanisms involved in immunological defence over the lifespan is relatively sparse and often contentious. Ever since the early 1800's, nutrients have been recognized for their regulatory effects on immune function [4]. Most nutrients are needed for upholding healthy immune functions and deficiency in almost any nutrient will lead to compromised immune functions [5].

For normal immune function, mandatory levels of nutrients range from trace to bulk quantities. Nutrients are generally required to synthesize new molecules during development of immune responses and for cell differentiation that occurs during clonal expansion of adaptive immune cells resulting in large enough numbers of antigen-specific effectors which attack and destroy the invading pathogens.

Impaired immune responses induced by malnutrition can increase susceptibility to infection and illness, which can in turn exacerbate states of malnutrition, for example, by reducing nutrient intake through diminished appetite, impairing nutrient absorption, increasing nutrient losses, or altering the body's metabolism such that nutrient requirements are increased [6]. Thus, states of malnutrition and infection can aggravate each other and lead to the establishment of a vicious circle [1].

Our knowledge of the effects of nutrition on immune function now extends beyond clinical nutrient deficiency. A growing body of literature demonstrates the immune benefits of increasing the intake of specific nutrients. This article will review our current understanding of the role of several nutrients in maintaining host immune defence. An inadequate status of some of these nutrients occurs in many populations in the world, where infectious diseases are a major health concern. We will also review nutrients that may specifically modulate host defence to pathogens.

We begin with a review of the immune system and its components with the main focus on the adaptive immune arm and the role of T-lymphocytes. We also review what particular changes are brought by aging in nutrition and the immune system. Given the limitation of space for the current issue and because we are unable to review all nutrients that are needed to maintain immune function, readers are directed to some seminal and excellent reviews presented in Table 1 and some other work published on this and the relevant topics throughout the text.

\section{The immune system}

\subsection{A brief overview}

A detailed description of the immune system and the disorders associated with it is beyond the scope of this review. Therefore, readers are referred to some seminal work on the topic elsewhere [7-9]. Briefly, however, the immune system is a complex organ that includes elements involved in numerous functions in a cohesive mode with other body systems. For protection against foreign agents (bacteria, viruses, parasites, fungi, yeast, pollen, dietary proteins, toxins, cancer cells, etc.), a first line of defence includes physical barriers and certain chemicals such as skin and mucosa (nasal, intestinal, etc.), their secretions ( $\mathrm{pH}$ of stomach acid, lysozyme, and other antibacterial components sweat and other secretions) and protective native flora.

Once pathogens have traversed this first barrier, the immune system is responsible for defence mechanisms that can be divided into two categories: 1) innate immune responses which are specific for shared microbial factors not found in mammals, respond rapidly via non-polymorphic cell surface receptors and do not mediate immune memory; 2) adaptive immune response (also called acquired immunity), able to recognize myriads of short peptides derived from target cells detected by highly specific polymorphic cell surface receptors and mediating immune memory. Both innate and adaptive immunity act via immune-competent cells (leukocytes) and a number of soluble factors (e.g., complement, antibodies, cytokines etc) $[10,11]$.

The cells involved in the immune response originate in the bone marrow; they mostly reside in lymphoid organs such as thymus, spleen, lymph nodes and Peyer's patches, and are also disseminated throughout the body in the bloodstream, skin, gut and lung epithelium and lymphatic circulation and directed towards where they are required in each case depending on the type of pathogen and its location [12]. Within the immune system, innate phagocytic cells comprising neutrophils, granulocytes, basophils and eosinophils, monocytes and macrophages act rapidly as first line of defence without prior exposure 
Table 1

Summary of nutrients affecting the immune system and metabolic health

\begin{tabular}{|c|c|c|c|}
\hline Nutrients & Functions & $\begin{array}{l}\text { Review or key } \\
\text { references on } \\
\text { immune effects }\end{array}$ & $\begin{array}{l}\text { Review or key } \\
\text { references on } \\
\text { metabolic health } \\
\quad \text { effects }\end{array}$ \\
\hline Energy/Protein & $\begin{array}{l}\text { - Energy required for producing proteins and generating new immune } \\
\text { cells in order to fight infection } \\
\text { - Amino acids have been demonstrated to play important roles in immune } \\
\text { responses by regulating, a) the activation of T-Lymphocytes; } \\
\text { b) lymphocytes, NK cells, and macrophages; c). cellular redox state, } \\
\text { gene expression, and lymphocyte proliferation; and d). the production of } \\
\text { antibodies, cytokines, and other factors }\end{array}$ & {$[118-123]$} & {$[124-132]$} \\
\hline $\begin{array}{l}\text { Fats } \\
\text { - Monounsaturated fats } \\
\text { - } \alpha \text {-linoleic acid (n-6 PUFA) } \\
\text { - } \gamma \text { linolenic acid (n-6 PUFA) } \\
\text { - } \mathrm{n}-3 \text { PUFA }\end{array}$ & $\begin{array}{l}\text { - Source of energy } \\
\text { - Structures of cell membranes } \\
\text { - Signaling molecules } \\
\text { - Inflammatory response }\end{array}$ & {$[122,133-136]$} & [137-139] \\
\hline Folic Acid & $\begin{array}{l}\text { - Immune gene regulation } \\
\text { - DNA and protein synthesis }\end{array}$ & {$[140-143]$} & {$[144-151]$} \\
\hline Vitamin A & $\begin{array}{l}\text { - NK Cell Activity } \\
\text { - Activation of inflammatory response } \\
\text { - Differentiation of T cell subsets } \\
\text { - Migration of T cells into tissues, proper development of T cell- } \\
\text { dependent antibody responses }\end{array}$ & {$[152-154]$} & {$[156,157]$} \\
\hline Vitamin B12 & - As co-enzyme for methionine and L-methylmalonyl-CoA & {$[158-160]$} & {$[161,162]$} \\
\hline Vitamin B6 & $\begin{array}{l}\text { - Endogenous synthesis } \\
\text { - Metabolism of amino acids } \\
\text { - Lymphocyte proliferation } \\
\text { - Differentiation, and maturation as well as cytokine and antibody } \\
\text { production }\end{array}$ & {$[73,163-166]$} & {$[167,168]$} \\
\hline Vitamin C & $\begin{array}{l}\text { - Antioxidant } \\
\text { - Stimulation and production of leucocytes } \\
\text { - Cellular motility, chemotaxis and phagocytosis }\end{array}$ & {$[6,77,169,170]$} & {$[171-173]$} \\
\hline Vitamin D & - Monocyte proliferation, production of IL-1 & {$[155]$} & {$[124,174,175]$} \\
\hline Vitamin E & $\begin{array}{l}\text { - Improved natural killer (NK) } \\
\text { cytotoxic activity, neutrophil chemotaxis, phagocytic response } \\
\text { - Enhanced mitogen-induced lymphocyte proliferation and interleukin-2 } \\
\text { (IL-2) production }\end{array}$ & {$[71,176-178]$} & [179-180] \\
\hline Copper & $\begin{array}{l}\text { - Thymus growth and integrity } \\
\text { - Functional component of a number of essential enzymes known as } \\
\text { cuproenzymes, } \\
\text { - Antimicrobial }\end{array}$ & {$[81,90,181]$} & {$[182,183]$} \\
\hline Iron & $\begin{array}{l}\text { - Structural part of proteins and enzymes that are involved in oxygen } \\
\text { transport and storage, electron transport and energy generation, } \\
\text { antioxidant and beneficial pro-oxidant functions, and DNA synthesis, } \\
\text { - Differentiation and proliferation of T-Lymphocytes and generation of } \\
\text { reactive oxygen species (ROS), } \\
\text { - Phagocytic function, } \\
\text { - Cytokine production, } \\
\text { - Complement system activation }\end{array}$ & {$[83,84,184-188]$} & {$[189,190]$} \\
\hline Zinc & $\begin{array}{l}\text { - Immune signaling pathways } \\
\text { - Immune functions of zinc can be divided into three categories: } \\
\text { 1. catalytic, 2. structural, and } \\
\text { 3. regulatory }\end{array}$ & [191-195] & {$[182,196]$} \\
\hline
\end{tabular}


Table 1

(Continued)

\begin{tabular}{llcc}
\hline Nutrients & Functions & $\begin{array}{c}\text { Review or key } \\
\text { references on } \\
\text { immune effects }\end{array}$ & $\begin{array}{c}\text { Review or key } \\
\text { references on } \\
\text { metabolic health } \\
\text { effects }\end{array}$ \\
\hline $\begin{array}{l}\text { Alcohol/Wine (Note: alcohol/wine } \\
\text { only in moderate amounts have } \\
\text { beneficial effects) }\end{array}$ & $\begin{array}{l}\text { - Anti-inflammatory effect } \\
\text { - Protects against DNA damage }\end{array}$ & {$[196,197]$} & {$[198-201]$} \\
& $\begin{array}{l}\text { - Attenuates monocyte inflammatory response } \\
\text { - Absolute values of leucocytes, monocytes, lymphocytes increase }\end{array}$ & Concentrations of IgG, IgM, IgA increase \\
& - IL-2, IL-4 and IL-10 concentrations increase
\end{tabular}

to the pathogen by recognising structures not present in mammals ("pathogen-associated molecular patterns", PAMPs). By contrast, the adaptive response requires more specific specialized cells, the lymphocytes, acting through specific recognition of a much wider array of antigens from the microorganisms that have attacked the body. These cells thus are accomplished at generating cell clones specifically against the challenge in question, and retaining specific immunological memory for any future challenge by the same pathogen. Lymphocytes are classified into $\mathrm{T}$ and $\mathrm{B}$ lymphocytes and immunocompetent natural killer cells (NK), the latter included within innate immunity in general, although their participation in the adaptive mechanisms is becoming increasingly evident [13].

T-Lymphocytes are divided in turn into 'collaborators' (or helper; usually distinguished by the presence of the molecule CD4 + on the surface) and 'cytotoxic/suppressor' (usually characterized by the CD8 + molecule on the surface), both involved in cell-mediated immunity or cellular immunity [14]. The B lymphocytes are responsible for generation of soluble antibodies (immunoglobulins, 'Igs'), the fundamental components of humoral immunity. These molecules circulating in plasma and infiltrate the tissues body-wide. Of course, the above is a very brief picture of the overall protection provided by the interaction between different cells (mature B and various types of T cells) and a large multiplicity of molecules that are part of the immune response (complement factors, enzymes, cytokines and antibodies, etc.) [13].

\subsection{Aging and changes in the immune signatures}

There are large changes in human immune profiles along the lifespan. A brief overview of these changes is given in the following sections.

\subsubsection{Fetal life}

In utero, the fetal setting requires that the immune system remains tolerant to maternal alloantigens. After birth, abrupt exposure to environmental antigens, many of them resulting from intestinal commensal bacteria, demands a swift transformation to make discrete immune responses appropriate for early life. The innate immune system offers an early first line of defense against assaulting pathogens. The cells involved are neutrophils, monocytes, macrophages and dendritic cells, which all interact with the adaptive immune system. These cells develop and mature during fetal life, but at diverse times, and the function of all components of innate immunity is frail in newborns compared with later life. Mature neutrophils are already present at the end of the first trimester and precipitously increase in number, stimulated by granulocytecolony-stimulating factor, just before birth. Their number then returns to a steady level within days, but they display feeble bactericidal functions, meager responses to inflammatory stimuli, weak adhesion to endothelial cells and reduced chemotaxis [15]. These shortfalls are more conspicuous in preterm infants, which also have lower serum IgG and complement. Consequently, the newborn, and particularly premature infants, have compromised neutrophil functions [16], putting the child at increased risk of bacterial infections. In preterm and newborn infants, typical monocytes and macrophages are also undeveloped. They have reduced TLR4 expression with impaired innate signalling pathways [17-19], resulting in reduced cytokine responses compared with adults. Subsequently, there is poor tissue repair, weakened phagocytosis of potential pathogens and poor secretion of bioactive molecules. However, while there is a reduced frequency of pulmonary macrophages in premature and term infants, adult levels of these cells are reached within days after birth [20]. 
Mature single CD4 and CD8 positive T cells are first identified in the thymus at week 15 and are numerous in the periphery well before birth [21, 22]. However, neonatal $\mathrm{T}$ cells differ significantly from adult cells, perhaps because during fetal life, contact to foreign antigens is largely limited to non-inherited maternal alloantigens. The function of early-life $T$ cells is different from adult $\mathrm{T}$ cells. For example, although fetal naive $\mathrm{CD} 4+\mathrm{T}$ cells respond powerfully to alloantigens, they tend to mature towards Foxp $3+\mathrm{CD} 25+$ regulatory $\mathrm{T}$ cells (Treg) through the effect of TGF-b [23], and thus vigorously support self-tolerance. Peripheral regulatory $\mathrm{T}$ cells (Tregs) make up around $3 \%$ of total CD4 + T cells at birth [6] and these cells are maintained for a long time [24], giving the early-life immune response an antiinflammatory profile [25].

\subsubsection{Newborns and infants}

In the newborn, in addition to conventional $\mathrm{T}$ cells that distinguish peptide antigens in the context of classical MHC molecules, there are populations of $\gamma \delta$ T-cell receptor (TCR)-positive and innate-like $\alpha \beta$ TCR-positive T cells. These comprise functionally competent iNKT cells that swiftly produce IFN, mucosal-associated invariant $\mathrm{T}$ (MAIT) cells [26] and the newly designated interleukin-8 (CXCL8)secreting naive $\mathrm{T}$ cells that bond innate and adaptive immunity [27]. Children with low gestational weight plus atrophy may exhibit reduced thymus size and display attenuated cellular immunity. On the other hand, it has been found that children who are born underweight have fewer T-Lymphocytes and lower responses to mitogens. The delayed hypersensitivity skin test is also impaired in these cases. Children with low gestational weight show a poor cellular immune response for several months or even years. This result is especially relevant in children whose weight-height is below $80 \%$ of normal [28].

The immune system gradually develops during infancy. Precarious early protection against many infectious diseases hitherto experienced by the mother is given by the passive IgG antibody transferred from the mother through the placenta and in the milk. Besides promoting survival, such antigen stimulation results in immunological memory [29, 30].

At the time of birth, nearly all $\mathrm{T}$ cells express the CD45RA glycoprotein, typical of naive T cells, which have never encountered foreign antigen. There are also comparatively plentiful Tregs within the CD45RA-negative CD4 + T cell population. During childhood, Treg numbers decline, and memory Th1, Th17 and Th2 cells progressively increase [31].

\subsubsection{Adulthood and old age}

It is believed that with increasing age the immune system has a decreased ability to mediate adequate defence against micro-organisms, malignant cells and other "foreign" agents. The course of aging is associated with amplified free radical production, contributing to the decreased immune response [32]. The changes in the immune system are associated with decreased responses in the skin hypersensitivity test, lower production of IL-2, reduced response to mitogens and antigens, and lower-titer antibodies after vaccination. Also, the capacity of immunocompetent cells is reduced for clonal proliferation and generation of $\mathrm{B}$ and $\mathrm{T}$ cells and a marked decrease in the activity of thymus and reduced production of serum IgA, and even decreased primary antibody responses. The number of T-Lymphocytes is marginally decreased, although the number of CD8 + cells has been reported as similar, decreased or even increased (reviwed in 33). Furthermore, those functions that are more associated with stress, such as adhesion, production of free radicals and cytokines, increase with age $[32,34]$. As age progresses, the immune system experiences intense remodeling and weakening, with major effects on health and survival [35]. This immune senescence predisposes older adults to a higher risk of acute viral and bacterial infections. Moreover, the mortality rates of these infections are three times higher among elderly patients compared with younger adult patients [36].

Infectious diseases are still the fourth most common cause of death among the elderly in the developed world. The figures are even more worrisome for the developing world. Furthermore, anomalous immune responses in the aged can aggravate inflammation, conceivably contributing to other diseases of old age: cancer, cardiovascular disease, stroke, Alzheimer's disease and dementia, for example [37]. T cells proliferate and increase the "virtual memory' compartment, but at the same time, the ability to establish immunological memory in response to de-novo antigens is reduced, compromising vaccinations. Functions such as cytokine production by CD4 and CD8 T cells are diminished, the expression of key surface markers is altered and the CD4 + to CD8 + T-cell ratio may become inverted [35]. The expanded T-cell responses that keep latent viruses such as EBV and CMV under control, reduces space for $\mathrm{CD} 8+\mathrm{T}$ cells specific for other potentially lethal 
viruses [38], exacerbated by the reduced thymic naive T-cell output. Interestingly, aging presents a unique paradox i.e., it is associated with an increase in the autoimmunity and inflammation that coexist with immunodeficiency [39]. Immunosenescence is a broad concept that reflects the immunological changes associated with age [40-43] and inflammatory potential of the diet [44].

\section{Nutrition and the immune system}

In the following section, our discussion will mainly focus on the relationship between nutrition and the immune system. We will elaborate on this relationship using data collected mainly in human studies (age 60 and above) throughout this paper. However, results of studies using animal models will also be discussed wherever needed. In vivo experiments are widely used to investigate the effects of nutritional interventions on immune-related parameters in animal models which can be challenging in humans. Many studies conducted on human populations in developing countries identify deficiencies in macronutrients (fats, proteins, carbohydrates that lead to protein-energy deficiency), micronutrients (minerals, electrolytes and vitamins that lead to micronutrients deficiency) or both (reviewed in Ref. 45). These studies are very relevant because they permit the identification of the most severely affected regions and consequently can guide intervention by humanitarian organizations and local governments. Nonetheless, laboratory animals have been very useful in studying the effects of different levels of malnutrition, because non-nutritional factors that affect humans can be controlled in this type of evaluation [46]. The use of animal models in malnutrition has yielded a great deal of information on molecular mechanisms involved in the greater susceptibility to infections and also to immunodeficiency secondary to undernutrition.

The most commonly employed models are adult mice and rats (outbred or isogenic) fed with reduced amount of proteins, vitamins or micronutrients [47]. The long history of animal experimentation describes the use of a series of methods that not only include the use of whole animals but isolated organs, isolated tissues, tissue cultures, isolated cells, subcellular components, modeling and structure-activity relationships [48]. As immunodeficiency associated with prepubescent malnutrition underlies a very high burden of infection-related morbidity, acute weanling mice have also been explored to investigate the effects of malnutrition [49]. More recently, transgenic and knockout mice have also been employed to better understand the mechanisms involved in the greater susceptibility to infectious agents in malnourished mice [49] and for studying wound healing [50]. These numerous animal models allowed a growing understanding and characterization of the immunological disturbances triggered by under-nutrition. Some examples of the most relevant findings in this research area are presented in (Table 1).

The disciplines of nutrition and immunology and their interdependency were formally recognized and documented in the 1970s when immunological measures were introduced as a constituent of nutritional status assessment $[4,5]$. Understanding of the effect of nutrients on immune function has been refined with the progressive growth of the field of immunology from relatively descriptive science to one in which diverse immune mechanisms can be integrated together coherently and explained in clear-cut structural and biochemical terms. For some time, protein energy malnutrition (PEM) has been considered the major cause of immunodeficiency worldwide [51]. This is not surprising because immune cells have a high requirement for energy and amino acids for cell division and protein synthesis. The influence of PEM on immune function has been reviewed extensively [52-58] and also studied widely, particularly in the context of effects of PEM on viral susceptibility [59, 60], PEM and supressed immunity, PEM and impaired immune organ growth [61] and PEM and thymic atrophy [62].

All nutrients have specific roles in the overall functional capacity of the immune system. For example, certain antioxidants play a key role in protecting immunocompetent cells against oxidative stress [32]. Protein and energy have been studied extensively in relation to immune functions, particularly with an emphasis on their role in overall metabolism (Table 1). Vitamins, minerals and trace elements play an important role as cofactors in many metabolic pathways and are considered essential for the integrity and optimal functioning of the immune system. Some micronutrients such as vitamin A (beta-carotene), folic acid, vitamin B6, vitamin B12, vitamin $\mathrm{C}$, vitamin $\mathrm{E}$, iron, zinc, copper and selenium, exert immunomodulatory effects influencing host vulnerability to infections [63-65].

Malnutrition in humans is generally perceived as a syndrome with numerous nutrient deficiencies. The 
impact of micronutrients on immunocompetence has been explored extensively, albeit mostly by experiments on laboratory animals using diets deficient in micronutrients resulting in the development of clinical symptoms of diseases of the immune system. These immunological changes were reversed when animals were fed diets supplemented with those missing elements, noting also that excessive supplementation could result in adverse effects on the immune system [64]. At the same time, obesity, another highly prevent form of malnutrition, has been extensively studied in relation to immunity. The overall impact of obesity on immunity has been recently investigated with looking at obesity as a form of 'lowgrade chronic inflammation' (reviewed in 66).

It has been noted that insufficiency of certain vitamins causes a decrease of thymus and spleen size, a drop in the activity of NK cells, lower levels of the pro-inflammatory and anti-viral cytokine interferon$\gamma($ IFN- $\gamma$ ), a decrease in the delayed hypersensitivity skin response, and a low response to mitogen stimulation by lymphocytes $[67,68]$. The results of a number of studies concerning supplementation of diets with beta-carotene have shown an escalation in the number of helper T-Lymphocytes and capacity of NK cells. When such supplementation was performed for relatively long periods in elderly subjects, an increase was also observed in the activity of NK cells. In both experimental animals and humans, it has been shown that supplementation with beta-carotene stimulates cellular immunity and humoral immunity and hence may exert a preventive effect against the incidence of certain diseases [69].

An appropriate intake of vitamin $\mathrm{E}$ is essential for proper functioning of the immune system. Out of eight naturally occurring forms of vitamin E; namely, the alpha, beta, gamma and delta classes of tocopherol and tocotrienol, alpha-tocopherol and gammatocopherol are common forms in supplements and diets and have been usually found to affect immunity (reviwed in Ref. 70, 71). In a small intervention study in older adults (mean age, 70 years), supplementation with $200 \mathrm{mg} /$ day of all-rac- $\alpha$-tocopherol (equivalent to $100 \mathrm{mg}$ of $R R R$ - $\alpha$-tocopherol) for three months significantly improved natural killer (NK) cytotoxic activity, neutrophil chemotaxis, phagocytic response, and enhanced mitogen-induced lymphocyte proliferation and interleukin-2 (IL-2) production compared to baseline [71]. $\alpha$-Tocopherol has been shown to enhance specifically the $T$ cell-mediated immune response that declines with advancing age [70-73]. It has been shown that deficiency of this nutrient is associated with an impaired immune response, producing alterations in humoral immunity, cellular immunity and phagocytic functions $[72,73]$. Recommended intakes of vitamin $\mathrm{E}$ might be sufficient to prevent the onset of neuropathies and myopathies, but only reverse effects of deficiencies rather than amplify normal immune system, a consideration which applies to all such supplementation studies. The immunostimulatory effect of vitamin $\mathrm{E}$ increases the resistance of an individual to certain infectious diseases, possibly mediated by increased generation of antibodies as well as augmentation of phagocytic activity [72, 73]. Due to its antioxidant effects, the amount of vitamin $\mathrm{E}$ needed depends on the severity of the process which triggers oxidative stress (i.e. consumption of diets high in polyunsaturated fatty acids, the presence of certain diseases and aging). It is established that administering high doses of vitamin E may result in improvement of both humoral immunity and cellular immunity [72]. However, it has also been proposed that the beneficial effect of supplementation with vitamin E may be limited to those individuals who have a severe deficiency of vitamin $E$ as a result of intestinal malabsorption [74].

Vitamin C also affects some parameters of the immune system with deficiency predisposing to infections, especially of the upper respiratory tract. The risk of this type of infection is increased especially in individuals who practice intense physical exercise. In this context, immunological changes of both innate immunity (activity NK cells, phagocytic function and oxidative neutrophils) and specific immunity (function of $\mathrm{T}$ cells and $\mathrm{B}$ ) have been reported. Due to the antioxidant action of vitamin $\mathrm{C}$, supplementation with this micronutrient is often recommended. For example, it was reported that vitamin $\mathrm{C}$ supplementation results in an improvement in the immune system and a lower incidence of infections [75]. Vitamin $\mathrm{C}$ has been shown to affect the immune system by (A) exciting the production [76] and function [77] of leukocytes; (B) enhancing cellular motility and chemotaxis and phagocytosis [77]; (C) promoting neutrophil activity [78], (D) increase in the serum levels of antibodies and C1q complement proteins $[79,80]$.

Analogous results are seen when there are deficits of minerals and trace elements. Iron, zinc, copper and selenium are needed for proper operation of the immune system and are essential for adequate protection against infections [81]. Iron is the most prevalent deficient mineral in most parts of the world and its 
deficiency is associated with an increase in morbidity and indisposition from infectious disease as shown by earlier work, both in animals and humans, conducted over the past two decades. Iron is an essential element for the proper development of the immune system [13]. It has been found that iron supplementation in populations showing deficits in this element decreases the frequency of infectious episodes. Iron deficiency causes a failure in the defence mechanisms of individuals reflected in reduced phagocytic capability, a lower response to stimulation of lymphocytes, a decrease in the number NK cell associated with lower production of IFN-g, and low delayed hypersensitivity cutaneous responses [82]. Iron is an essential component of hundreds of proteins and enzymes that are involved in oxygen transport and storage, electron transport and energy generation, antioxidant and beneficial pro-oxidant functions, and DNA synthesis [83]. Iron is required for effective immune responses against pathogens, and iron deficiency impairs immune responses [84]. Sufficient iron is critical to several immune functions, including the differentiation and proliferation of $\mathrm{T}$ lymphocytes and generation of reactive oxygen species (ROS) that kill pathogens. However, iron is also required by most infectious agents for replication and survival. During an acute inflammatory response, serum iron levels decrease while levels of ferritin (the iron storage protein) increase, suggesting that impounding iron from pathogens is an important host response to infection [83]. Nonetheless, conditions of iron overload (e.g., hereditary hemochromatosis) can also have deleterious effects on immune function, such as diminishing phagocytic function, cytokine production, complement system activity, and $\mathrm{T}$ and $\mathrm{B}$ lymphocyte function [84]. Further, data from the first National Health and Nutrition Examination Survey (NHANES), a US national survey, indicate that raised iron levels may be a risk factor for cancer and death, especially in men [85]. For men and women combined, there were significant tendencies for increasing risk of cancer and mortality with increasing transferrin saturation, with risks being higher in those with transferrin saturation $>40 \%$ compared to $\leq 30 \%$ [85].

Zinc is also a good example to illustrate the concept of how the lack of a single nutrient can affect the immune system. In this sense, the literature on the studies showing its deficiency is unequivocal [86, 87]. Zinc is required for the activity of more than 100 metallo-enzymes [88]. Zinc affects multiple aspects of the immune system from the skin barrier to gene regulation in lymphocytes, influences the function of cells mediating non-specific immunity (neutrophils and NK cells), but also has a role in the induction of specific immunity by acting on the activation of T-Lymphocytes, cytokine production and maturation of B lymphocytes [86]. Thus, zinc deficiency is associated with lymphoid attenuation and a decrease in the proliferative response of lymphocytes to mitogens and lower thymic hormone activity [87]. Moreover, experimental evidence shows a decrease in the ratio CD4/CD8. Zinc deficiencies cause an imbalance in Th1 and Th2 function, a decreased production of IL2, IFN-g and TNF-a, while the production of IL-4, IL-6 and IL-10 is not altered [87].

Copper is also an essential micronutrient for development, growth and maintenance of the immune system; being necessary for differentiation, maturation and activation of various types of immunocompetent cells and for cytokine secretion, thus exercising an impact on host defence. It also plays a role synthesis of haemoglobin and myoglobin, and acts as an antioxidant, since it is an indispensable cofactor for a large variety of enzymes, including cytochrome $\mathrm{C}$ oxidase and $\mathrm{Cu}, \mathrm{Zn}$-superoxide dismutase [89]. Recently, it has been observed in adult rats and healthy individuals in vitro that the activity of $\mathrm{T}$ cells is reduced when the diet is deficient in copper, suggesting that ample/increased intake of this micronutrient would reduce the chances of suffering from infectious disease [90]. It has also been shown that insufficient copper intake has adverse consequences for innate and acquired immunity. In this respect, $T$ cells appear to be more affected than $\mathrm{B}$ cells, and the microbicidal activity of neutrophils and macrophages as well as the cytolytic activity of NK cells is reduced; hypersensitivity and antibody production in vitro in response to mitogens is also affected under these conditions [89].

\section{Nutrition, metabolism and immunity}

Nutrition and immunity are closely related. In the past few decades, this relationship has been explored and reported extensively. The overall picture emerges from a large body of work that nutrition affects immunity via changes in metabolism and metabolic pathways. Therefore, any discussion on relationships between nutrition and immunity can only be understood by comprehending metabolism and metabolic changes that are associated with nutritional 
status. Accumulating data support the notion that understanding how metabolism regulates immune cell function could provide new therapeutic opportunities for the many diseases associated with immune system dysregulation.

One of the important aims in the study of nutrition and immunity is to determine the role of nutrients affecting metabolism of the body (general/organismal metabolism) and hence immunity. Immune cells migrate throughout the body and sometimes take up residence in niche environments with distinct and varied communities of cells, extracellular matrix, and nutrients that may differ from those in which they matured. Imbedded in immune cell physiology are metabolic pathways and metabolites that not only provide energy and substrates for growth and survival, but also instruct effector functions, differentiation, and gene expression [91]. Studies have shown that dietary intakes rich in whole-grain foods have been related to a lower prevalence of a metabolic syndrome (MetSyn) [92, 93], which is a clustering of certain conditions i.e. increased blood pressure, elevated blood sugar, excess body fat around the waist, and abnormal cholesterol or triglyceride levels, insulin resistance, that occur together, increasing risk of diabetes (Type-II) and cardiovascular abnormalities. The association is less reliable for refined-grain intake, with some cross-sectional studies recording a positive association and others no relation [92]. Dairy intake has been shown to be associated with MetSyn both in cross-sectional and prospective studies [94-96]. Higher intakes of fruit and vegetables have also been associated with a lower prevalence of MetSyn [93]. No association has been found between MetSyn and intakes of meat and fish [95]. Intakes of regular and diet soda, however, have been positively associated with MetSyn both cross-sectionaly and prospectively [97]. In cross-sectional dietary pattern analyses, a higher prevalence of MetSyn was found among consumers of "Western" [98] and "empty-calorie" [99] dietary patterns, whereas a lower prevalence was found among those consuming a "healthy" dietary pattern $[98,99]$.

The intake of diets that are lower in carbohydrate, lower in saturated fat, but higher in protein than the average American diet - which consists of almost $47 \%$ carbohydrate, $38 \%$ fat (20\% SFA), and $15 \%$ protein - have a tendency to be beneficial for improving features of the metabolic syndrome, including effects on insulin sensitivity and blood lipids [99]. In particular, insulin resistance has been recognized as a chronic inflammatory and metabolic disease, playing a pivotal role in the development of diabetes [100]. Obesity and abnormal lipid metabolism increases infiltration of inflammatory cells, affects immune homeostasis, and reduces insulin sensitivity, consequently leading to the occurrence of insulin resistance. [100]. In their study, Musselman et al. found that obesity-associated insulin resistance led to increased susceptibility of flies to infection, as in humans [100].

There have been many proposed dietary patterns claiming health benefits ranging from those related to metabolic and immune health. For example, the Mediterranean dietary pattern [45-48, 73, 99, 101, 102], Ornish Diet [50, 103, 104], Atkins Diet [105, 106], Zone Diet [107], the South Beach Diet [108] etc. Adherence to these diets in relation to metabolic health and expansion in the immune parameters have been studied extensively. The Mediterranean dietary pattern, in particular has fascinated nutritionists focused in immunity. This diet, high in fruits, vegetables and olive oil, and fish consumption [109] has been shown to be related to anti-inflammatory processes [110-112] and thus has been recommended for the maintenance of health [113].

In the discussion of nutrition and immune interplay, obesity in particular has attracted a great deal of attention. Obesity is considered as a state of chronic inflammation, which affects both the metabolic health and the immune system in a number of ways. For example, adipose tissue is considered to be responsible for a possible link between obesity and the immune system (reviewed by de Heredia et al., [114]. Histological studies in mice showed that macrophage infiltration in adipose tissue was greater in obese than in lean animals [115]. Macrophages appeared as crown-shaped aggregates, similar to those observed in other known inflammatory conditions, such as rheumatoid arthritis, and grew larger with increasing degrees of obesity. This finding led to the idea that macrophage aggregates could partially explain the obesity-related inflammatory state. There are of higher rates of infections and impaired wound healing in obese subjects [116]. Excess body fat is accompanied by changes in leucocyte counts, with elevated leucocyte, neutrophil, monocyte and lymphocyte counts, but lower T- and B-cell mitogeninduced proliferation [116]. In addition, other studies have shown that the production of antibodies after vaccination is diminished in obese patients [116, 117]. 


\section{What is the mechanism whereby nutrition affects the immune system?}

The mechanisms behind immunological alterations with respect to nutrition are still not adequately understood. Nevertheless, there have been many theories put forward to explain this phenomenon. For example, the lack of energy and the amino acid building blocks to synthesize the required proteins in marasmic children may be one possible cause [202]. However, lack of building blocks does not explain why some immune parameters seem unaffected or paradoxically even raised in malnutrition, such as plasma IgA, acute-phase proteins, leucocytes in blood, and production of Th2 cytokines. If it was solely a matter of lack of building blocks, all parameters of the immune system should be affected in the same way. Other explanations include a confounding role of infections in influencing immune parameters in malnourished individuals [203], low levels of certain hormones in malnourished children, e.g. leptin [204], prolactin [205] and growth hormone [206], all of which impact growth and function of thymus - an important specialized primary lymphoid organ where $\mathrm{T}$ cells mature till puberty. In support of this, a recent study found that a low leptin level was associated with a higher risk of death in malnourished children [207]. Growth hormone therapy has been found to augment thymic size and output in adult HIV + patients [208]. In contrast, cortisol and adrenalin prompt thymic atrophy in mice [209, 210], and cortisol is high in children with malnutrition and other forms of stress. Zinc deficiency causes thymic atrophy [211, 212], and acute phase responses lower plasma zinc, so zinc status may contribute to the immune deficiency of both malnutrition and acute phase responses.

The intracellular receptor, mammalian target of Rapamycin (mTOR), is present in most cells. It responds to the concentrations of nutrients in the cell's surroundings, enabling the cell to adapt its metabolism to locally available nutrients. Immune cells also use mTOR to regulate their state of activation. Nutrient availability may thereby determine whether an immune cell is activated [213], and whether T-cells differentiate towards a proinflammatory or a tolerance-inducing phenotype [214]. Some immune cells may even deplete the microenvironment of certain nutrients, to manipulate the activation of mTOR. Accordingly, the significance of nutrients in the microenvironment expands from simple building blocks to signal molecules. Obviously, this mechanism could be involved in the immunological profile in malnutrition. However, no publications have yet described the activity of mTOR in malnourished children. A research group working with animal models of malnutrition has proposed a theory called the "tolerance hypothesis" [215]. This suggests that the depression of cellular immunity in malnutrition is an adaptive response to prevent autoimmune reactions, which would otherwise occur as a result of catabolism and release of self-antigens. Such phenomena have apparently not been studied further.

\section{Effects of aging on nutrition}

The relation between aging and nutrition is complex one as what affects what is difficult to decide. Natural aging cannot be stopped but can be delayed by nutritional interventions. This is the main theme of discussions on relationships between aging and nutrition in this section of the paper. The aging process involves changes in pathological, physiological, social, and psychological conditions of individuals. Nutrition is an important element of health in the elderly, and it affects the whole process of aging [216]. The prevalence of malnutrition is cumulative in this population and is related to weakening functional status, diminished muscle function, reduced bone mass, immune dysfunction, anemia, diminished cognitive function, poor wound healing, delayed recovery from surgery, higher hospital readmission rates, and mortality. Due to altering socioeconomic environments, elderly people are often left alone to fend for themselves to maintain their health, which may hinder the maintenance of a good nutritional status.

Nutritional choices remain crucial throughout life, having great influence on overall health and wellness of the individual and potentially also generations to come due to developmental programing. All healthy people need the same basic nutrients, including carbohydrates, essential amino acids, essential fatty acids, and as many as 28 vitamins and minerals, in order to maintain life and health and reproduce successfully. However, the amounts of needed nutrients change as an individual passes from one stage of life to the next. Clearly, young children require a higher caloric intake relative to body size to facilitate physical and mental development as compared to the elderly [216-218]. It is also important to note that nutrition at one particular stage of life span may 
be profoundly reflected in another stage, particularly during the latter years. This can be seen in the findings of a number of studies based $[219,220]$ on the famous historical famine known as "the Dutch Hunger Winter". The famine was a humanitarian disaster, but it left an opportunity to study the effects of maternal malnutrition on the offspring's health and ageing in later life. Using birth records of babies born around the time of the Dutch famine in the Amsterdam area, the long-term consequences of pre-natal undernutrition have been investigated [219]. It has been shown that those who were conceived during the famine - and had thus been undernourished during the earliest stages of their development-have an increased risk for coronary heart disease, diabetes, an atherosclerotic lipid profile, altered clotting and breast cancer.

The relationship between nutrition and aging, complex as it is, has a bidirectional association, i.e., aging affects nutrition and vice versa (Table 2). However, in the forthcoming section, we will restrict ourselves mainly to the discussion on how aging may affect nutrition. In general, there is a decline in the overall nutritional status with aging - a fact confirmed by both cross-sectional as well as longitudinal studies [219-221]. This age-associated decline in nutritional status may be more obvious in societies with low economy, literacy rate and lack of nutrition-related awareness. Nevertheless, the so called Westernized, Educated, Intelligent, Rich, and Democratic (WEIRD) societies also suffer from ageassociated malnutrition in one way or the other. Extraordinary changes in the regulation of energy intake in the elderly as compared to the young have been extensively reported [222-227]. The day-to-day variability in energy intake (20\%-25\%) and energy expenditure $(10 \%)$ [228, 229] suggests substantial fluctuation in day-to-day energy balance. Energy balance in old age is significantly impaired as compared to that in young age suggesting markedly impaired regulation of energy intake in late life [224, 225]. There are also several animal studies conducted in the past that reported impaired regulation of food intake in old age [225, 230-238].

Old age is often associated with reduced hunger and early satiety due to a number of physical, physiological and social reasons (reviewed in 225, 239-242). Several studies have recorded abnormally low hunger following fasting or experimental induction of negative energy balance in elderly subjects [222-224, 227, 238, 243-245]. Alterations in glucose homeostasis in old age may contribute to altered hunger and satiety. Blood glucose has long been a postulated trigger for hunger signals in both rodents and humans [240, 246-249]. In addition, delayed gastric emptying in general has been linked to reduced hunger and increased satiety [222, 246, 250-252]. Also, taste and smell of food play important roles in regulating intake, and impairment in old age has been reported to be partly responsible for reduced hunger signals and thus lower intake [225, 253-258]. Hunger and satiety are also related to food variety; a characteristic of food that has been reported to play a pivotal role in overall food intake [227, 259, 260]. A study [260] recently reported on the long-term association between dietary variety and body fatness in healthy adult men and women.

Many studies examining gastric emptying in relation to age have reported a decreased rate of gastric emptying in the elderly [222, 261-264]; a phenomenon responsible for a number of other related complications including disturbance in those hormone systems related to energy regulation [243, 252, 264, 267]. Some well-known examples are glucagon (responsible for the signals of satiation) [243, 252, 264-267], which has been reported [249] to be significantly elevated by up to $25 \%$ in response to consumption of meals of $2,092 \mathrm{~kJ}(500 \mathrm{kcal})$ or greater, identifying a potential role for glucagon in the apparently enhanced satiation associated with old age. Similarly, another satiety hormone CCK, has been shown to be as much as 5-fold higher in the elderly than in young adults, particularly following consumption of diets with high fat content [268-271].

Basal Metabolic Rate (BMR) is a strong surrogate indicator of the physiological functioning of various organs. Age associated physiological changes in the organ system brings about adverse changes in energy expenditure, resulting in a fall in BMR with aging. In addition, there is a decrease in thermic energy, total energy expenditure and physical activity level. Also there is a decline in energy expenditure responsiveness to energy imbalance [249, 316-318]. A seminal work by Keys et al. [318] documented a decline in BMR with age, which was as much as $1-2 \%$ per decade. In this way, during the life span stage of 20-70 years of age, a reduction in BMR of about $400 \mathrm{~kJ} /$ day can be predicted based on the findings [318] Age-associated reduction in BMR may be mainly due to changes in the body composition in old age [317]. Changes in body composition with aging (more adipose tissue, lesser lean body mass), also cause drastic decline in thermic effect of feeding, which is equivalent to nearly $8-15 \%$ of ingested 
Table 2

Summary of nutrients affecting aging

\begin{tabular}{|c|c|c|}
\hline Nutrients & Effects related to old age & $\begin{array}{c}\text { Key } \\
\text { References }\end{array}$ \\
\hline Carbohydrates & $\begin{array}{l}\text { - Increased glucose intake accelerates aging } \\
\text { - High concentrations of glucose in media accelerate the senescence of cultured human cells } \\
\text { - Other carbohydrates or carbohydrate metabolites, including trehalose, pyruvate, malate, fumarate, and N- } \\
\text { acetylglucosamine (GlcNAc), have been shown to promote longevity in C. elegans } \\
\text { - Low-carbohydrate diet is beneficial for human health } \\
\text { - Age-related diseases including diabetes and heart diseases }\end{array}$ & {$[190,272-282]$} \\
\hline Protein & $\begin{array}{l}\text { - Low-protein/high-carbohydrate diet is associated with long lifespan. } \\
\text { - High animal-protein intake positively correlates with the risk of developing urothelial cell carcinoma, } \\
\text { whereas high plant-protein intake negatively correlates with the risk }\end{array}$ & [283-285] \\
\hline Fats & $\begin{array}{l}\text { - A high-fat diet (HFD) is generally associated with increased mortality and increased incidence of many } \\
\text { metabolic diseases, including type II diabetes and cardiovascular problems } \\
\text { - Diets enriched in unsaturatedfattyacidsleadtoreducedbloodlevelsofharmfullow-density lipoproteins and } \\
\text { increased levels of protective high-density lipoproteins } \\
\text { - Diets enriched in natural unsaturated } \\
\text { fattyacidslowerbloodpressure,improveinsulinsensitivity,andreducethe risks of cardiovascular and } \\
\text { metabolic diseases } \\
\text { - Dietary trans-fats (unsaturated fatty acids with trans-isomers) trigger inflammatory responses, which } \\
\text { increase the risks of developing cardiovascular and metabolic diseases } \\
\text { - Arachidonic acids, which are omega (x)-6 PUFAs, induce apoptosis of cancer cells } \\
\text { - Dietary lipids may affect mammalian health and longevity by altering the compositions of body fat and } \\
\text { cellular membranes. }\end{array}$ & {$[276,286-296]$} \\
\hline $\begin{array}{l}\text { Vitamins and } \\
\text { Minerals }\end{array}$ & $\begin{array}{l}\text { - Vitamin E/tocopherol intake significantly increases the lifespan of rotifers, nematodes, and fruit flies } \\
\text { - Supplementation of vitamin C/ascorbic acid, a well-known antioxidant, increases the lifespan of the bean } \\
\text { beetle Callosobruchus maculatus } \\
\text { Many members of the vitamin B family also lengthen the lifespan of flies, Zucker fatty rats, and C. } \\
\text { elegans, a mega-dose of vitamins and minerals mildly increases human mortality } \\
\text { selenium (Se), an antioxidant mineral, significantly reduces DNA breakage and extends the replicative } \\
\text { lifespan of cultured adrenocortical cells }\end{array}$ & [297-315] \\
\hline
\end{tabular}

metabolizable energy. Some studies report a decrease in the thermic effect of feeding in old age, while other studies report no change [249, 318].

Old age is also responsible for a decrease in energy expenditure responsiveness to energy imbalance. In this way energy balance is drastically disturbed in old age [319]. A decrease or increase in energy intake is normally triggered by the energy expenditure of the body. Any disruption in this mechanism, as usually observed in old age, will result in malnutrition (i.e. underweight as a result of underfeeding or overweight/obesity as a result of overfeeding. The consequences in case of overfeeding are particularly crucial in case when fat is ingested above the requirements - a condition necessarily demanding for the extra fat to be stored by the body as the ability of fat oxidation decreases with aging [321].

Daily energy expenditure consists of basal or resting energy expenditure, diet-induced thermogenesis and that associated with activity [322]. Changes in all components may occur with age. Firstly, as lean mass drops, BMR in relation to body weight falls off, although per $\mathrm{kg}$ fat-free mass remains unchanged or only somewhat diminished. Second, with diminished food intake there is less diet-induced thermogenesis; third, activity lessens, particularly with disability. These changes, despite the age-related decline in energy intake, result in a positive energy balance in middle life and the changes in body composition described above. Finally with the onset of anorexia in the very old, energy balance becomes negative and BMI and fat mass decline. Similarly, anorexia and weight loss associated with chronic disease may also be associated with a fall in BMR. These changes have an effect on the immune system.

\section{Conclusion and future outlook}

In short, in the previous sections, we have provided a brief overview for understanding how diet and nutritional factors influence immune functions, thereby regulating health and disease outcomes. Beyond providing essential nutrients, diet can actively influence the immune system. Naturally occurring compounds 
like vitamins and minerals modulate immune responses. We also see changes in the immune system with normal aging which may be partially a function of changes in overall nutrition at various life stages. The challenge remains to capture these interactions and complexities to better understand nutritional immunology in the context of aging. In this review, several aspects of this complexity have been explored. We first gave an overview of the immune system, and its mode of action. To characterize interactions between nutrition and immunity, we discussed the effects of multiple food components on immune functions. In the next sections, we discussed effects of aging and finally we discussed effects of aging on the immune system.

We further emphasize the fact that both nutrition and immunity are complex and multi-dimensional traits. The same is true for normal aging. Aging, nutrition and immunity ("aging nutrimmunity") hence form a complex network and nutritional interactions via multiple direct and indirect pathways. Future research will need to focus on how these pathways interact with each other and explore nutrient allocation strategies of the body, and the effects of aging thereon. Excellent initial work in this connection includes the "selfish brain" theory [323] and "the "selfish immune system" theory [324], which we will analyse in separate reviews. We believe that there is need for both further research as well as for the development of theoretical frameworks in the particular discipline of nutritional immunology of old age which we propose to term "aging nutrimmunity". In short, as argued by Stanga [322], five main conclusions concerning nutrition and immunity in the elderly can be drawn: firstly, immunological decline is not an inevitable part of ageing; thus, many elderly subjects maintain vigorous immune responses at a level that is comparable to that seen in younger subjects. Second, nutritional deficiencies are quite common in this old age; a large proportion of the elderly show evidence of PEM or selected nutrient deficiencies. Third, correction of nutritional deficiencies does improve immune responses even in old age. Fourth, appropriate nutritional counselling and dietary therapy, sometimes with medicinal supplements, results in reduced respiratory illness. And fifth, multivitamin, multi-mineral supplements in the elderly can lead to improved lymphocyte function and fewer infections.

As we have previously reported that the aged are already having a malfunctioning in their energy metabolism, energy allocation mechanisms and inflammation [325], more exposed to proinflammatory diets [44], have negative changes in their body composition and have compromised immunity [326-328]. There is a need of studies that look into the combined effects of diet with various life style factors, for example, sleeping, exercise, sun exposure and social issues. The area of discussion on nutrition, immune and aging relationship is much extensive, wide and varied that this is beyond the scope of a single review. However, a snapshot of such a relation was presented here in the present review. It is suggested that in future the following areas of research may be addressed:

1. Randomized controlled trials that include older adults with disease and $\mathrm{n}$ use to make nutrient recommendations within these altered metabolic states.

2. Randomized controlled trials in various life stages for prevention of mild cognitive decline and in different stages of Alzheimer disease with patient-tailored lifestyle nutrition treatments for evidence to support individual or broad recommendations on diet, lifestyle, or nutrient supplementation.

3. Studies examining other biomarkers beyond nitrogen balance to fully understand the impact of advancing age on protein requirements and skeletal muscle protein turnover.

4. Clinical trials to establish optimal nutrient requirements and to identify food components for older adults to improve immune function and reduce inflammatory diseases Design of an effective, interoperable electronic medical record, integrated across health care settings, to promote improved documentation and communication across health care providers, enhance care coordination, and facilitate continuity in nutrition care as an older individual transitions between health care settings.

5. Re-evaluation of how the current BMI guidelines are used in older adults and incorporation of nutrition screening and assessment into general practice and community settings.

\section{Disclosure}

All authors disclose 'no conflict of interest'.

\section{Funding}

The authors report no funding. 


\section{Acknowledgments}

We acknowledge the Deanship of Scientific Research, College of Applied Medical Sciences Research Center at King Saud University, Riyadh, Saudi Arabia. The fist author, in particular, also extends his appreciation to the Deutscher Akademischer Austauschdienst (DAAD), Germany, for financial support (scholarship) for his PhD studies. This material is the result of work for his $\mathrm{PhD}$ supported by DAAD.

\section{References}

[1] Katona P, Katona-Apte J. The interaction between nutrition and infection. Clinical Infectious Diseases. 2008;46(10):1582-8.

[2] Norman K, Pichard C, Lochs H, Pirlich M. Prognostic impact of disease-related malnutrition. Clinical Nutrition. 2008;27(1):5-15.

[3] Schaible UE, Kaufmann SHE. Malnutrition and Infection: Complex Mechanisms and Global Impacts. Plos Medicine. 2007;4(5):e115.

[4] Beisel WR. History of nutritional immunology: Introduction and overview. Journal of Nutrition. 1992;122(3 Suppl):591-6.

[5] Shils, Maurice E. Modern Nutrition in Health and Disease, 6th Edition: Williams \& Wilkins; 1994. pp. 148.

[6] Takahata Y, Nomura A, Takada H, Ohga S, Furuno K, Hikino S, et al. CD25+CD4+T cells in human cord blood: An immunoregulatory subset with naive phenotype and specific expression of forkhead box p3 (Foxp3) gene. Experimental Hematology. 2004;32(7):622-9.

[7] Punt J. Adaptive Immunity: T Cells and Cytokines. In: Cancer Immunotherapy (2nd Edition); 2013. pp. 41-53.

[8] Fulop T, Franceschi C, Hirokawa K, Pawelec G. Handbook on Immunosenescence: Springer Netherlands; 2009. pp. 2519-29.

[9] Peakman M, Vergani D. Basic and Clinical Immunology E-Book: Elsevier Health Sciences; 2009.

[10] Parkin J, Cohen B. An overview of the immune system: The Lancet. Lancet. 1997;357(9270):629-53.

[11] Levinson WE. Review of Medical Microbiology and Immunology 15th ed. McGraw Hill Professional; 2018.

[12] Parham P. The immune system: 2nd ed. Ch. 12. Garland Science; 2014.

[13] Kutteh WH, Stanic AK, Schust DJ. Immunology and reproduction. In: Yen and Jaffe's Reproductive Endocrinology (8th Edition); 2019. pp. 301-321.

[14] Köhl J. Self, non-self, and danger: A complementary view. Advances in Experimental Medicine \& Biology. 2006;586(586):71.

[15] Nussbaum C, Gloning A, Pruenster M, Frommhold D, Bierschenk S, Genzel-Boroviczény O, et al. Neutrophil and endothelial adhesive function during human fetal ontogeny. Journal of Leukocyte Biology. 2013;93(2):175-84.

[16] Filias A, Theodorou GL, Mouzopoulou S, Varvarigou AA, Mantagos S, Karakantza M. Phagocytic ability of neutrophils and monocytes in neonates. BMC Pediatrics. 2011;11(1):29.

[17] Yan SR, Qing G, Byers DM, Stadnyk AW, Al-Hertani W, Bortolussi R. Role of MyD88 in diminished tumor necrosis factor alpha production by newborn mononuclear cells in response to lipopolysaccharide. Infection and Immunity. 2004;72(3):1223-9.

[18] Sadeghi K, Berger A, Langgartner M, Prusa A-R, Hayde $\mathrm{M}$, Herkner $\mathrm{K}$, et al. Immaturity of infection control in preterm and term newborns is associated with impaired tolllike receptor signaling. The Journal of Infectious Diseases. 2007;195(2):296-302.

[19] Al-Hertani W, Yan SR, Byers DM, Bortolussi R. Human newborn polymorphonuclear neutrophils exhibit decreased levels of MyD88 and attenuated p38 phosphorylation in response to lipopolysaccharide. Clinical \& Investigative Medicine. 2007;30(2):44-53.

[20] Blahnik MJ, Ramanathan R, Riley CR, Minoo P. Lipopolysaccharide-induced tumor necrosis factor- $\alpha$ and IL-10 production by lung macrophages from preterm and term neonates. Pediatric Research. 2001;50(6):726-31.

[21] Haddad R, Guimiot F, Six E, Jourquin F, Setterblad N, Kahn $\mathrm{E}$, et al. Dynamics of thymus-colonizing cells during human development. Immunity. 2006;24(2):217-30.

[22] Zlotoff DA, Schwarz BA, Bhandoola A, editors. The long road to the thymus: The generation, mobilization, and circulation of T-cell progenitors in mouse and man. Seminars in immunopathology; 2008: Springer.

[23] Mold JE, Venkatasubrahmanyam S, Burt TD, Michaëlsson J, Rivera JM, Galkina SA, et al. Fetal and adult hematopoietic stem cells give rise to distinct $\mathrm{T}$ cell lineages in humans. Science. 2010;330(6011):1695-9.

[24] Burlingham WJ, Grailer AP, Heisey DM, Claas FH, Norman D, Mohanakumar T, et al. The effect of tolerance to noninherited maternal HLA antigens on the survival of renal transplants from sibling donors. New England Journal of Medicine. 1998;339(23):1657-64.

[25] Mackroth MS, Malhotra I, Mungai P, Koech D, Muchiri E, King CL. Human cord blood CD4+CD25hi regulatory T cells suppress prenatally acquired $\mathrm{T}$ cell responses to Plasmodium falciparum antigens. The Journal of Immunology. 2011;186(5):2780-91.

[26] Leeansyah E, Loh L, Nixon DF, Sandberg JK. Acquisition of innate-like microbial reactivity in mucosal tissues during human fetal MAIT-cell development. Nature Communications. 2014;5:3143.

[27] Silva-Santos B, Schamel WW, Fisch P, Eberl M. $\gamma \delta$ Tcell conference 2012: Close encounters for the fifth time. European Journal of Immunology. 2012;42(12):3101-5.

[28] Marcos A. Actualización en nutrición, inmunidad e infección. Nutrición Hospitalaria. 2004;19(1):53.

[29] Walker JM, Slifka MK. Longevity of T-cell memory following acute viral infection. Memory T Cells: Springer; 2010. pp. 96-107.

[30] Zinkernagel RM. On immunological memory. Philosophical Transactions of the Royal Society of London B: Biological Sciences. 2000;355(1395):369-71.

[31] Shearer WT, Rosenblatt HM, Gelman RS, Oyomopito R, Plaeger S, Stiehm ER, et al. Lymphocyte subsets in healthy children from birth through 18 years of age: The Pediatric AIDS Clinical Trials Group P1009 study. Journal of Allergy and Clinical Immunology. 2003;112(5):973-80. 
[32] De 1FM. Effects of antioxidants on immune system ageing. European Journal of Clinical Nutrition. 2002;56(supplement 3):S5.

[33] Pawelec G. Immune signatures associated with mortality differ in elderly populations from different birth cohorts and countries even within northern Europe. Mechanisms of Ageing and Development. 2018;177:182-185.

[34] Victor VM, Fuente MDl. N-acetylcysteine improves in vitro the function of macrophages from mice with endotoxin-induced oxidative stress. Free Radical Research. 2002;36(1):33-45.

[35] Moro-García MA, Alonso-Arias R, López-Larrea C. When aging reaches CD4+ T-cells: phenotypic and functional changes. Frontiers in Immunology. 2013;10;4:107.

[36] Yoshikawa TT. Epidemiology and unique aspects of aging and infectious diseases. Clinical Infectious Diseases. 2000;30(6):931-3.

[37] Chung HY, Cesari M, Anton S, Marzetti E, Giovannini S, Seo AY, et al. Molecular inflammation: Underpinnings of aging and age-related diseases. Ageing Research Reviews. 2009;8(1):18-30.

[38] De Martinis M, Franceschi C, Monti D, Ginaldi L. Inflamm-ageing and lifelong antigenic load as major determinants of ageing rate and longevity. FEBS Letters. 2005;579(10):2035-9.

[39] Sardi F, Fassina L, Venturini L, Inguscio M, Guerriero F, Rolfo E, Ricevuti G. Alzheimer's disease, autoimmunity and inflammation. The good, the bad and the ugly. Autoimmunity Reviews. 2011;11(2):149-53.

[40] Boraschi D, Italiani P. Immunosenescence and vaccine failure in the elderly: Strategies for improving response. Immunology Letters. 2014;162(1):346-53.

[41] Fulop T, Le Page A, Fortin C, Witkowski JM, Dupuis G, Larbi A. Cellular signaling in the aging immune system. Current Opinion in Immunology. 2014;29:105-11.

[42] Poland GA, Ovsyannikova IG, Kennedy RB, Lambert ND, Kirkland JL. A systems biology approach to the effect of aging, immunosenescence and vaccine response. Current Opinion in Immunology. 2014;29:62-8.

[43] Pawelec G, Akbar A, Caruso C, Solana R, GrubeckLoebenstein B, Wikby A. Human immunosenescence: Is it infectious? Immunological Reviews. 2005;205(1):257-68.

[44] Alam I, Shivappa N, Hebert JR, Pawelec G, Larbi A. Relationships between the inflammatory potential of the diet, aging and anthropometric measurements in a cross-sectional study in Pakistan. Nutrition and Healthy Aging.(Preprint):1-9.

[45] King FS, Burgess A, Quinn VJ, Osei AK, editors. Nutrition for developing countries. Oxford University Press; 2015.

[46] Ponton F, Wilson K, Cotter SC, Raubenheimer D, Simpson SJ. Nutritional immunology: A multi-dimensional approach. PLoS Pathogens. 2011;7(12):e1002223.

[47] McMullen S, Mostyn A. Animal models for the study of the developmental origins of health and disease: Workshop on 'Nutritional models of the developmental origins of adult health and disease'. Proceedings of the Nutrition Society. 2009;68(3):306-20.

[48] Vasconcelos CA. Animal models of human nutritional diseases: A short overview. Revista brasileira de hematologia e hemoterapia. 2012;34(4):264.

[49] França TG, Ishikawa LL, Zorzella-Pezavento SF, ChiusoMinicucci F, da Cunha ML, Sartori A. Impact of malnutrition on immunity and infection. Journal of Venomous Animals and Toxins including Tropical Diseases. 2009;15(3):374-90.

[50] Grose R, Werner S. Wound healing studies in transgenic and knockout mice. InWound Healing 2003 (pp. 191-216). Humana Press, Totowa, NJ.

[51] Delafuente JC. Nutrients and immune responses. Rheumatic Diseases Clinics of North America. 1991;17(2):203.

[52] Shlisky J, Bloom DE, Beaudreault AR, Tucker KL, Keller HH, Freund-Levi Y, et al. Nutritional Considerations for Healthy Aging and Reduction in Age-Related Chronic Disease. Advances in Nutrition. 2017;8(1):17.

[53] Prieto I, Montemuiño S, Luna J, Torres MVD, Amaya E. The role of immunonutritional support in cancer treatment: Currentevidence. Clinical Nutrition. 2016.

[54] Bharadwaj S, Trivax B, Tandon P, Alkam B, Hanouneh I, Steiger E. Should perioperative immunonutrition for elective surgery be the current standard of care? Gastroenterology Report. 2016;4(2):87-95.

[55] Chow O, Barbul A. Immunonutrition: Role in Wound Healing and Tissue Regeneration. Advances in Wound Care. 2014;3(1):46.

[56] Calder PC. Feeding the immune system. Proceedings of the Nutrition Society. 2013;72(3):299-309.

[57] Woodward B. Protein, Calories, and Immune Defenses. Nutrition Reviews. 1998;56(2):84-92.

[58] Cooper EL, Ma MJ. Understanding nutrition and immunity in disease management. Journal of Traditional \& Complementary Medicine. 2017.

[59] Sultan MT. Protein-Energy Malnutrition: A Risk Factor for Various Ailments. Critical Reviews in Food Science \& Nutrition. 2015;55(2):242-53.

[60] Osman A. Protein Energy Malnutrition and Susceptibility to Viral Infections as Zika and Influenza Viruses. J Nutr Food Sci. 2016;6(489):2.

[61] Moore SE, Fulford AJ, Wagatsuma Y, Persson LÅ, Arifeen SE, Prentice AM. Thymus development and infant and child mortality in rural Bangladesh. International Journal of Epidemiology. 2013;43(1):216-23.

[62] Rytter MJ, Kolte L, Briend A, Friis H, Christensen VB. The Immune System in Children with Malnutrition-A Systematic Review. PLoS One. 2014;9(8):e105017.

[63] Chandra RK. Nutrition and the immune system: An introduction. American Journal of Clinical Nutrition. 1997; 66(2):460S.

[64] Calder PC, Kew S. The immune system: A target for functional foods? British Journal of Nutrition. 2007;88(S2):S165.

[65] Padbidri BMD. Micronutrient Malnutrition, Infection, and Immunity: An Overview. Nutrition Reviews. 2010;60(s5):S40-S5.

[66] Alam I, Pawelec G. Aging, nutrition and immunity-their relationship and interaction. Nutrition and Aging. 2012;1(3, 4):151-65.

[67] Gross RL, Newberne PM. Role of nutrition in immunologic function. Physiological Reviews. 1980;60(1):188-302.

[68] Bhaskaram P. Immunobiology of mild micronutrient deficiencies. British Journal of Nutrition. 2007;85(S2): S75.

[69] Chew BP, Park JS. Carotenoid action on the immune response. J Nutr 134:257S-261S. 2004;134(1):257S-61S. 
[70] Wu D, Meydani SN. Age-associated changes in immune function: Impact of vitamin e intervention and the underlying mechanisms. Endocrine Metabolic \& Immune Disorders Drug Targets. 2014;14(4):283-9.

[71] Fuente MDL, Hernanz A, Guayerbas N, Victor VM, Arnalich F. Vitamin E ingestion improves several immune functions in elderly men and women. Free Radical Research. 2008;42(3):272-80.

[72] Maksimovskaja NS. Recent developments in vitamin E and immune response. Nutrition Reviews. 1998;56(2):49-58.

[73] Meydani M, Harper AE. Effect of functional food ingredients: Vitamin E modulation of cardiovascular diseases and immune status in the elderly. American Journal of Clinical Nutrition. 2000;71(6 Suppl):1665S.

[74] Kowdley K, Meydani S, Cornwall S, Grand R, Mason J. Reversal of depressed T-lymphocyte function with repletion of vitamin E deficiency. Gastroenterology. 1992;102:1-4.

[75] Peters-Futre EM. Vitamin C, neutrophil function, and upper respiratory tract infection risk in distance runners: The missing link. Exercise Immunology Review. 1997;3(1): 32-52.

[76] Levy R, Shriker O, Porath A, Riesenberg K, Schlaeffer F. Vitamin $\mathrm{C}$ for the treatment of recurrent furunculosis in patients with imparied neutrophil functions. Journal of Infectious Diseases. 1996;173(6):1502-5.

[77] Anderson R. The immunostimulatory, antiinflammatory and anti-allergic properties of ascorbate. Advances in Nutritional Research. 1984;6:19-45.

[78] Feigen GA, Smith BH, Dix CE, Flynn CJ, Peterson NS, Rosenberg LT, et al. Enhancement of antibody production and protection against systemic anaphylaxis by large doses of vitamin C. Research Communications in Chemical Pathology \& Pharmacology. 1982;38(2):313-33.

[79] Johnston CS, Kolb WP, Haskell BE. The effect of vitamin $\mathrm{C}$ nutriture on complement component $\mathrm{C} 1 \mathrm{q}$ concentrations in guinea pig plasma. Journal of Nutrition. 1987;117(4): 764-8.

[80] Padayatty SJ, Katz A, Wang Y, Eck P, Kwon O, Lee JH, Chen S, Corpe C, Dutta A, Dutta SK, Levine M. Vitamin $\mathrm{C}$ as an antioxidant: Evaluation of its role in disease prevention. Journal of the American college of Nutrition. 2003;22(1):18-35.

[81] Failla ML. Trace elements and host defense: Recent advances and continuing challenges. Journal of Nutrition. 2003;133(1):1443S-7S.

[82] Cunningham-Rundles S. Nutrient modulation of the immune response: Newyork, Marcel: Dekker; 1993.

[83] Beard JL. Iron biology in immune function, muscle metabolism and neuronal functioning. Journal of Nutrition. 2001;131(2S-2):568S.

[84] Doherty CP. Host-pathogen interactions: The role of iron. Journal of Nutrition. 2007;137(5):1341-4.

[85] Stevens RG, Graubard BI, Micozzi MS, Neriishi K, Blumberg BS. moderate elevation of body iron level and increased risk of cancer occurrence and death. 2015. pp. 447-52.

[86] Dardenne M. Zinc and immune function. European Journal of Clinical Nutrition. 2002;56(s3):S20.

[87] Prasad AS. Effects of Zinc Deficiency on Th1 and Th2 Cytokine Shifts. Journal of Infectious Diseases. 2000; 182(Suppl 1):S62.
[88] Scrimshaw NS, Sangiovanni JP. Synergism of nutrition, infection, and immunity: An overview. American Journal of Clinical Nutrition. 1997;66(2):464S.

[89] Percival SS. Copper and immunity. The American journal of clinical nutrition. 1998;67(5):1064S-8S.

[90] Bonham M, O'Connor JM, Hannigan BM, Strain J. The immune system as a physiological indicator of marginal copper status? British Journal of Nutrition. 2002;87(5):393403.

[91] Buck MD, Sowell RT, Kaech SM, Pearce EL. Metabolic instruction of immunity. Cell. 2017;169(4):570-86.

[92] McKeown NM, Meigs JB, Liu S, Saltzman E, Wilson PW, Jacques PF. Carbohydrate nutrition, insulin resistance, and the prevalence of the metabolic syndrome in the Framingham Offspring Cohort. Diabetes Care. 2004;27(2):538-46.

[93] Esmaillzadeh A, Kimiagar M, Mehrabi Y, Azadbakht L, $\mathrm{Hu}$ FB, Willett WC. Fruit and vegetable intakes, C-reactive protein, and the metabolic syndrome. The American Journal of Clinical Nutrition. 2006;84(6):1489-97.

[94] Azadbakht L, Mirmiran P, Esmaillzadeh A, Azizi F. Dairy consumption is inversely associated with the prevalence of the metabolic syndrome in Tehranian adults. The American Journal of Clinical Nutrition. 2005;82(3):523-30.

[95] Mennen LI, Lafay L, Feskens EJ, Novak M, Lépinay P, Balkau B. Possible protective effect of bread and dairy products on the risk of the metabolic syndrome. Nutrition Research. 2000;20(3):335-47.

[96] Pereira MA, Jacobs Jr DR, Van Horn L, Slattery ML, Kartashov AI, Ludwig DS. Dairy consumption, obesity, and the insulin resistance syndrome in young adults: The CARDIA Study. Jama. 2002;287(16):2081-9.

[97] Dhingra R, Sullivan L, Jacques PF, Wang TJ, Fox CS, Meigs JB, et al. Soft drink consumption and risk of developing cardiometabolic risk factors and the metabolic syndrome in middle-aged adults in the community. Circulation. 2007;116(5):480-8.

[98] Sonnenberg L, Pencina M, Kimokoti R, Quatromoni P, Nam BH, D'agostino R, et al. Dietary patterns and the metabolic syndrome in obese and non-obese Framingham women. Obesity. 2005;13(1):153-62.

[99] Serra-Majem L, Roman B, Estruch R. Scientific evidence of interventions using the Mediterranean diet: A systematic review. Nutrition Reviews. 2006;64(s1).

[100] Musselman LP, Fink JL, Grant AR, Gatto JA, Tuthill BF, Baranski TJ. A complex relationship between immunity and metabolism in Drosophila diet-induced insulin resistance. Molecular and Cellular Biology. 2018;38(2):e00259-17.

[101] ADA. Evidence-based nutrition principles and recommendations for the treatment and prevention of diabetes and related complications. Diabetes Care. 2002;25(1):202-12.

[102] Aude YW, Agatston AS, Lopez-Jimenez F, Lieberman EH, Almon M, Hansen M, et al. The national cholesterol education program diet vs a diet lower in carbohydrates and higher in protein and monounsaturated fat: A randomized trial. Archives of Internal Medicine. 2004;164(19):2141-6.

[103] Gould KL, Ornish D, Kirkeeide R, Brown S, Stuart Y, Buchi M, et al. Improved stenosis geometry by quantitative coronary arteriography after vigorous risk factor modification. The American Journal of Cardiology. 1992;69(9): 845-53. 
[104] Ornish D, Scherwitz LW, Billings JH, Gould KL, Merritt TA, Sparler S, et al. Intensive lifestyle changes for reversal of coronary heart disease. Jama. 1998;280(23):2001-7.

[105] Atkins RD. Dr. Atkins' new diet revolution: Government Institutes; 2002.

[106] Kossoff EH, Rowley H, Sinha SR, Vining EP. A prospective study of the modified Atkins diet for intractable epilepsy in adults. Epilepsia. 2008;49(2):316-9.

[107] Noakes M, Keogh JB, Foster PR, Clifton PM. Effect of an energy-restricted, high-protein, low-fat diet relative to a conventional high-carbohydrate, low-fat diet on weight loss, body composition, nutritional status, and markers of cardiovascular health in obese women. The American Journal of Clinical Nutrition. 2005;81(6):1298-306.

[108] Agatston A. The South Beach diet: The delicious, doctordesigned, foolproof plan for fast and healthy weight loss: Macmillan; 2005.

[109] Martínez-González MA, Zazpe I, Razquin C, SánchezTainta A, Corella D, Salas-Salvadó J, et al. Empiricallyderived food patterns and the risk of total mortality and cardiovascular events in the PREDIMED study. Clinical Nutrition. 2015;34(5):859-67.

[110] Medina-Remón A, Casas R, Tressserra-Rimbau A, Ros E, Martínez-González MA, Fitó M, et al. Polyphenol intake from a Mediterranean diet decreases inflammatory biomarkers related to atherosclerosis: A substudy of the PREDIMED trial. British Journal of Clinical Pharmacology. 2017;83(1):114-28.

[111] Neale E, Batterham M, Tapsell LC. Consumption of a healthy dietary pattern results in significant reductions in Creactive protein levels in adults: A meta-analysis. Nutrition Research. 2016;36(5):391-401.

[112] Tresserra-Rimbau A, Guasch-Ferré M, Salas-Salvadó J, Toledo E, Corella D, Castañer O, et al. Intake of total polyphenols and some classes of polyphenols is inversely associated with diabetes in elderly people at high cardiovascular disease risk. The Journal of Nutrition. 2016;146(4):767-77.

[113] Bonaccio M, Di Castelnuovo A, Costanzo S, Persichillo M, Benedetta M, Donati GdG, et al. Higher adherence to Mediterranean diet is associated with lower risk of overall mortality in subjects with cardiovascular disease: Prospective results from the MOLI-SANI study. Eur J Prev Cardiol. 2016;23(4):400-7.

[114] de Heredia FP, Gómez-Martínez S, Marcos A. Obesity, inflammation and the immune system. Proceedings of the Nutrition Society. 2012;71(2):332-8.

[115] Weisberg SP, McCann D, Desai M, Rosenbaum M, Leibel RL, Ferrante AW. Obesity is associated with macrophage accumulation in adipose tissue. The Journal of Clinical Investigation. 2003;112(12):1796-808.

[116] Marti A, Marcos A, Martinez JA. Obesity and immune function relationships. Obesity Reviews. 2001;2(2):131-40.

[117] Sheridan PA, Paich HA, Handy J, Karlsson EA, Hudgens MG, Sammon AB, Holland LA, Weir S, Noah TL, Beck MA. Obesity is associated with impaired immune response to influenza vaccination in humans. International Journal of Obesity. 2012;36(8):1072.

[118] Cunningham-Rundles S, McNeeley DF, Moon A. Mechanisms of nutrient modulation of the immune response. Journal of Allergy and Clinical Immunology. 2005;115(6): 1119-28.
[119] Almajwal A, Alam I, Zeb F, Fatima S. Energy Metabolism and Allocation in Selfish Immune System and Brain: A Beneficial Role of Insulin Resistance in Aging. Food and Nutrition Sciences. 2019;10:64-80.

[120] Kim SW, Mateo RD, Wu G, Carroll JA, Shinzato I. Dietary L-arginine supplementation affects immune status of pregnant gilts. The FASEB Journal. 2006;20(4):A424-A.

[121] Kim SW, Mateo RD, Yin Y-L, Wu G. Functional amino acids and fatty acids for enhancing production performance of sows and piglets. Asian Australasian Journal of Animal Sciences. 2007;20(2):295.

[122] Alphonse PA, Jones PJ. Revisiting human cholesterol synthesis and absorption: The reciprocity paradigm and its key regulators. Lipids. 2016;51(5):519-36.

[123] Erdman JW Jr, MacDonald IA, Zeisel SH. Present knowledge in nutrition: John Wiley \& Sons; 2012.

[124] Brennan IM, Luscombe-Marsh ND, Seimon RV, Otto B, Horowitz M, Wishart JM, et al. Effects of fat, protein, and carbohydrate and protein load on appetite, plasma cholecystokinin, peptide YY, and ghrelin, and energy intake in lean and obese men. American Journal of Physiology-Gastrointestinal and Liver Physiology. 2012;303(1):G129-G40.

[125] Scheja L, Heeren J. Introduction to the special issue on dietary control of immunometabolism. In: Seminars in immunopathology. Springer Berlin Heidelberg, 2018.

[126] Rui L. Energy metabolism in the liver. Comprehensive Physiology. 2011;4(1):177-97.

[127] Te Morenga L, Mallard S, Mann J. Dietary sugars and body weight: Systematic review and meta-analyses of randomised controlled trials and cohort studies. Bmj. 2013;346:e7492.

[128] Greenwood D, Threapleton D, Evans C, Cleghorn C, Nykjaer C, Woodhead C, et al. Association between sugarsweetened and artificially sweetened soft drinks and type 2 diabetes: Systematic review and dose-response metaanalysis of prospective studies. British Journal of Nutrition. 2014;112(5):725-34.

[129] Bhupathiraju SN, Pan A, Malik VS, Manson JE, Willett WC, van Dam RM, et al. Caffeinated and caffeine-free beverages and risk of type 2 diabetes. The American Journal of Clinical Nutrition. 2012:ajcn. 048603.

[130] Consortium I. Consumption of sweet beverages and type 2 diabetes incidence in European adults: Results from EPICInterAct. Diabetologia. 2013;56(7):1520-30.

[131] de Ruyter JC, Olthof MR, Seidell JC, Katan MB. A trial of sugar-free or sugar-sweetened beverages and body weight in children. New England Journal of Medicine. 2012;367(15):1397-406.

[132] Ebbeling CB, Feldman HA, Chomitz VR, Antonelli TA, Gortmaker SL, Osganian SK, et al. A randomized trial of sugar-sweetened beverages and adolescent body weight. New England Journal of Medicine. 2012;367(15): 1407-16.

[133] de Pablo MA, Ángeles Puertollano M, Álvarez De Cienfuegos G. Immune cell functions, lipids and host natural resistance. FEMS Immunology \& Medical Microbiology. 2000;29(4):323-8.

[134] Yaqoob P. Fatty acids as gatekeepers of immune cell regulation. Trends in immunology. 2003;24(12):639-45.

[135] Crevel R, Saul J. Linoleic acid and the immune response. European Journal of Clinical Nutrition. 1992;46(12):847. 
[136] Miles EA, Calder PC. Influence of marine n-3 polyunsaturated fatty acids on immune function and a systematic review of their effects on clinical outcomes in rheumatoid arthritis. British Journal of Nutrition. 2012;107(S2):S171S84.

[137] Alhazmi A, Stojanovski E, McEvoy M, Garg ML. Macronutrient intake and type 2 diabetes risk in middleaged Australian women. Results from the Australian Longitudinal Study on Women's Health. Public Health Nutrition. 2014;17(7):1587-94.

[138] Similä M, Kontto J, Valsta L, Männistö S, Albanes D, Virtamo J. Carbohydrate substitution for fat or protein and risk of type 2 diabetes in male smokers. European Journal of Clinical Nutrition. 2012;66(6):716.

[139] Mahendran Y, Ågren J, Uusitupa M, Cederberg H, Vangipurapu J, Stančáková A, et al. Association of erythrocyte membrane fatty acids with changes in glycemia and risk of type 2 diabetes. The American Journal of Clinical Nutrition. 2014:ajcn. 069740.

[140] Hudson NR. Present Knowledge in Nutrition 9th ed, Vol 1 (526 pages) and Vol 2 (967 pages), edited by Barbara A Bowman and Robert M Russell, 2006, hardcover, \$110. International Life Sciences Institute, Washington, DC. The American Journal of Clinical Nutrition. 2007;85(5): 1439-40.

[141] McStay CL, Prescott SL, Bower C, Palmer DJ. Maternal Folic Acid Supplementation during Pregnancy and Childhood Allergic Disease Outcomes: A Question of Timing? Nutrients. 2017;9(2):123.

[142] Mansouri R, Moogooei M, Moogooei M, Razavi N, Mansourabadi AH. The role of vitamin D3 and vitamin B9 (Folic acid) in immune system. International Journal of Epidemiologic Research. 2016;3(1):69-85.

[143] Dhur A, Galan P, Hercberg S. Folate status and the immune system. Progress in food \& Nutrition Science. 1991;15(12):43-60.

[144] Zheng X-X, Xu Y-L, Li S-H, Liu X-X, Hui R, Huang X$H$. Green tea intake lowers fasting serum total and LDL cholesterol in adults: A meta-analysis of 14 randomized controlled trials. The American Journal of Clinical Nutrition. 2011;94(2):601-10.

[145] Obersby D, Chappell DC, Dunnett A, Tsiami AA. Plasma total homocysteine status of vegetarians compared with omnivores: A systematic review and meta-analysis. British Journal of Nutrition. 2013;109(5):785-94.

[146] Liu X-D, Gao B, Sun D, Shi M, Ma Y-Y, Liu Z-R, et al. Prevalence of hyperhomocysteinaemia and some of its major determinants in Shaanxi Province, China: A cross-sectional study. British Journal of Nutrition. 2015;113(4):691-8.

[147] Katko M, Zavaczki E, Jeney V, Paragh G, Balla J, Varga Z. Homocysteine metabolism in peripheral blood mononuclear cells: Evidence for cystathionine beta-synthase activity in resting state. Amino Acids. 2012;43(1):317-26.

[148] Taguchi T, Mori H, Hamada A, Yamori Y, Mori M. Serum folate, total homocysteine levels and methylenetetrahydrofolate reductase $677 \mathrm{C}>\mathrm{T}$ polymorphism in young healthy female Japanese. Asia Pacific Journal of Clinical Nutrition. 2012;21(2):291-5.

[149] Ward M, Wilson CP, Strain J, Horigan G, Scott JM, McNulty H. B-vitamins, methylenetetrahydrofolate reduc- tase (MTHFR) and hypertension. International Journal for Vitamin and Nutrition Research. 2011;81(4):240-4.

[150] çetintaş VB, Gündüz C. Association between polymorphism of MTHFR c. $677 \mathrm{C}>\mathrm{T}$ and risk of cardiovascular disease in Turkish population: A meta-analysis for 2.780 cases and 3.022 controls. Molecular Biology Reports. 2014;41(1):397-409.

[151] Taban-Shomal O, Kilter H, Wagner A, Schorr H, Umanskaya N, Hübner U, et al. The cardiac effects of prolonged vitamin B12 and folate deficiency in rats. Cardiovascular Toxicology. 2009;9(2):95-102.

[152] Bhaskaram P. Immunobiology of mild micronutrient deficiencies. British Journal of Nutrition. 2001;85(S2):S75S80.

[153] Ross AC. Vitamin A and retinoic acid in T cell-related immunity. The American Journal of Clinical Nutrition. 2012;96(5):1166S-72S.

[154] Mora JR, Iwata M, Von Andrian UH. Vitamin effects on the immune system: Vitamins A and D take centre stage. Nature Reviews Immunology. 2008;8(9):685.

[155] Lin L, Liu Y, Ma G, Tan Z, Zhang X, Jiang J, et al. Survey on vitamin A deficiency in children under-6-years in China. Zhonghua yu fang yi xue za zhi (Chinese journal of preventive medicine). 2002;36(5):315-9.

[156] Chaves GV, Pereira SE, Saboya CJ, Ramalho A. Nonalcoholic fatty liver disease and its relationship with the nutritional status of vitamin A in individuals with class III obesity. Obesity Surgery. 2008;18(4):378-85.

[157] Van Dam RM, Willett WC, Rimm EB, Stampfer MJ, Hu FB. Dietary fat and meat intake in relation to risk of type 2 diabetes in men. Diabetes Care. 2002;25(3):417-24.

[158] Erkurt MA, Aydogdu I, Dikilitaş M, Kuku I, Kaya E, Bayraktar N, et al. Effects of cyanocobalamin on immunity in patients with pernicious anemia. Medical Principles and Practice. 2008;17(2):131-5.

[159] Tamura J, Kubota K, Murakami H, Sawamura M, Matsushima T, Tamura T, et al. Immunomodulation by vitamin B12: Augmentation of CD8+T-Lymphocytes and natural killer (NK) cell activity in vitamin B12-deficient patients by methyl-B12 treatment. Clinical \& Experimental Immunology. 1999;116(1):28-32.

[160] Watanabe S, Ide N, Ogawara H, Yokohama A, Mitsui T, Handa $\mathrm{H}$, et al. High Percentage of Regulatory T Cells before and after Vitamin B12 Treatment in Patients with Pernicious Anemia. Acta Haematologica. 2015;133(1): 83-8.

[161] Al Shamkani W, Jafar NS, Narayanan SR, Rajappan AK. Acute myocardial infarction in a young lady due to vitamin B12 deficiency induced hyperhomocysteinemia. Heart views: The Official Journal of the Gulf Heart Association. 2015;16(1):25.

[162] Cheng D, Kong H, Pang W, Yang H, Lu H, Huang C, et al. $\mathrm{B}$ vitamin supplementation improves cognitive function in the middle aged and elderly with hyperhomocysteinemia. Nutritional Neuroscience. 2016;19(10):461-6.

[163] Trakatellis A, Dimitriadou A, Trakatelli M. Pyridoxine deficiency: New approaches in immunosuppression and chemotherapy. Postgraduate Medical Journal. 1997;73(864):617-22.

[164] Rail LC, Meydani SN. Vitamin B6 and immune competence. Nutrition Reviews. 1993;51(8):217-25. 
[165] Paul L, Ueland PM, Selhub J. Mechanistic perspective on the relationship between pyridoxal 5'-phosphate and inflammation. Nutrition Reviews. 2013;71(4):239-44.

[166] Meydani SN, Ribaya-Mercado JD, Russell RM, Sahyoun N, Morrow FD, Gershoff SN. Vitamin B-6 deficiency impairs interleukin 2 production and lymphocyte proliferation in elderly adults. The American Journal of Clinical Nutrition. 1991;53(5):1275-80.

[167] Friso S, Girelli D, Martinelli N, Olivieri O, Lotto V, Bozzini $\mathrm{C}$, et al. Low plasma vitamin B-6 concentrations and modulation of coronary artery disease risk. The American Journal of Clinical Nutrition. 2004;79(6):992-8.

[168] Dhalla NS, Takeda S, Elimban V. Mechanisms of the beneficial effects of vitamin B6 and pyridoxal 5-phosphate on cardiac performance in ischemic heart disease. Clinical Chemistry and Laboratory Medicine. 2013;51(3):535-43.

[169] Jariwalla RJ, Harakeh S. Antiviral and immunomodulatory activities of ascorbic acid. Subcellular Biochemistry. 1996;25:215-32.

[170] Pauling L. How to live longer and feel better: Avon Books; 1987.

[171] Toh J, Tan VM, Lim PC, Lim S, Chong MF. Flavonoids from fruit and vegetables: A focus on cardiovascular risk factors. Current Atherosclerosis Reports. 2013;15(12):368.

[172] Aptekmann NP, Cesar TB. Long-term orange juice consumption is associated with low LDL-cholesterol and apolipoprotein B in normal and moderately hypercholesterolemic subjects. Lipids in Health and Disease. 2013;12(1): 119 .

[173] Morand C, Dubray C, Milenkovic D, Lioger D, Martin JF, Scalbert A, et al. Hesperidin contributes to the vascular protective effects of orange juice: A randomized crossover study in healthy volunteers. The American Journal of Clinical Nutrition. 2011;93(1):73-80.

[174] Kayaniyil S, Vieth R, Harris SB, Retnakaran R, Knight JA, Gerstein HC, et al. Association of $25(\mathrm{OH}) \mathrm{D}$ and PTH with metabolic syndrome and its traditional and nontraditional components. The Journal of Clinical Endocrinology \& Metabolism. 2011;96(1):168-75.

[175] Ju SY, Jeong HS, Kim DH. Blood vitamin D status and metabolic syndrome in the general adult population: A dose-response meta-analysis. The Journal of Clinical Endocrinology \& Metabolism. 2013;99(3):1053-63.

[176] Molano A, Meydani SN. Vitamin E, signalosomes and gene expression in T cells. Molecular Aspects of Medicine. 2012;33(1):55-62.

[177] De la Fuente M, Hernanz A, Guayerbas N, Manuel Victor V, Arnalich F. Vitamin E ingestion improves several immune functions in elderly men and women. Free Radical Research. 2008;42(3):272-80.

[178] Meydani SN, Meydani M, Blumberg JB, Leka LS, Siber G, Loszewski R, et al. Vitamin E supplementation and in vivo immune response in healthy elderly subjects: A randomized controlled trial. Jama. 1997;277(17):1380-6.

[179] Mah E, Sapper TN, Chitchumroonchokchai C, Failla ML, Schill KE, Clinton SK, et al. $\alpha$-Tocopherol bioavailability is lower in adults with metabolic syndrome regardless of dairy fat co-ingestion: A randomized, double-blind, crossover trial. The American Journal of Clinical Nutrition. 2015;102(5):1070-80.

[180] Del Ben M, Angelico F, Cangemi R, Loffredo L, Carnevale $\mathrm{R}$, Augelletti T, et al. Moderate weight loss decreases oxida- tive stress and increases antioxidant status in patients with metabolic syndrome. ISRN Obesity. 2012;2012.

[181] Percival SS. Copper and immunity. The American Journal of Clinical Nutrition. 1998;67(5):1064S-8S.

[182] Açik DY, Mescigil PF, Sayiner ZA. Do copper and zinc levels predict metabolic syndrome and metabolic syndrome's parameters as hs-CRP does? Gaziantep Medical Journal. 2015;21(3):196-9.

[183] Aguilar M, Saavedra P, Arrieta F, Mateos C, Gonzalez M, Meseguer I, et al. Plasma mineral content in type-2 diabetic patients and their association with the metabolic syndrome. Annals of Nutrition and Metabolism. 2007;51(5): 402-6.

[184] Brody T. Nutritional Biochemistry. 2nd Edition, Academic Press, San Diego, 1999.

[185] Beard J, Bowman B, Russell R. Present knowledge in nutrition. 9th ed. Washington DC: International Life Sciences Institute Press; 2006.

[186] Wood R, Ronnenberg A, King J, Cousins R, Dunns J, Burk $\mathrm{R}$, et al. Modern nutrition in health and disease. Shils, ME, Shike, M, Ross, AC, Caballero, B, and Cousins, RJ, Eds. 2006:248-70.

[187] Cassat JE, Skaar EP. Iron in infection and immunity. Cell Host \& Microbe. 2013;13(5):509-19.

[188] Prentice AM. Iron metabolism, malaria, and other infections: What is all the fuss about? The Journal of Nutrition. 2008;138(12):2537-41.

[189] Bouglé D, Brouard J. Iron in child obesity. Relationships with inflammation and metabolic risk factors. Nutrients. 2013;5(6):2222-30.

[190] Lee H-J, Jang HB, Park JE, Park K-H, Kang JH, Park SI, et al. Relationship between serum levels of body iron parameters and insulin resistance and metabolic syndrome in Korean children. Osong Public Health and Research Perspectives. 2014;5(4):204-10.

[191] Hojyo S, Fukada T. Roles of zinc signaling in the immune system. Journal of Immunology Research. 2016;2016.

[192] Haase H, Rink L. Zinc signals and immune function. Biofactors. 2014;40(1):27-40.

[193] Cousins R, Zinc I, Bowman B, Russell R. Present knowledge in nutrition. Present knowledge in nutrition. 1996.

[194] Bendich A. Micronutrients in women's health and immune function. Nutrition. 2001;17(10):858-67.

[195] Kruse-Jarres J. The significance of zinc for humoral and cellular immunity. Journal of Trace Elements and Electrolytes in Health and Disease. 1989;3(1):1-8.

[196] Romeo J, Wärnberg J, Nova E, Díaz LE, Gómez-Martinez $\mathrm{S}$, Marcos A. Moderate alcohol consumption and the immune system: A review. British Journal of Nutrition. 2007;98(S1):S111-S5.

[197] Szabo G, Mandrekar P. A recent perspective on alcohol, immunity, and host defense. Alcoholism: Clinical and Experimental Research. 2009;33(2):220-32.

[198] Ronksley PE, Brien SE, Turner BJ, Mukamal KJ, Ghali WA. Association of alcohol consumption with selected cardiovascular disease outcomes: A systematic review and meta-analysis. Bmj. 2011;342:d671.

[199] Brien SE, Ronksley PE, Turner BJ, Mukamal KJ, Ghali WA. Effect of alcohol consumption on biological markers associated with risk of coronary heart disease: Systematic review and meta-analysis of interventional studies. Bmj. 2011;342:d636. 
[200] Hvidtfeldt UA, Tolstrup JS, Jakobsen MU, Heitmann BL, Grønbæk M, O'reilly E, et al. Alcohol intake and risk of coronary heart disease in younger, middle-aged, and older adults. Circulation. 2010;121(14):1589-97.

[201] Chiva-Blanch G, Arranz S, Lamuela-Raventos RM, Estruch R. Effects of wine, alcohol and polyphenols on cardiovascular disease risk factors: Evidences from human studies. Alcohol and Alcoholism. 2013;48(3):270-7.

[202] Manary MJ, Yarasheski KE, Berger R, Abrams ET, Hart CA, Broadhead RL. Whole-body leucine kinetics and the acute phase response during acute infection in marasmic Malawian children. Pediatric Research. 2004;55(6):940-6.

[203] Wander K, Shell-Duncan B, Brindle E, O'Connor K. Predictors of delayed-type hypersensitivity to Candida albicans and anti-epstein-barr virus antibody among children in Kilimanjaro, Tanzania. American Journal of Physical Anthropology. 2013;151(2):183-90.

[204] Howard JK, Lord GM, Matarese G, Vendetti S, Ghatei MA, Ritter MA, et al. Leptin protects mice from starvation-induced lymphoid atrophy and increases thymic cellularity in ob/ob mice. Journal of Clinical Investigation. 1999;104(8):1051.

[205] De Mello-Coelho V, Savino W, Postel-Vinay M-C, Dardenne M. Role of prolactin and growth hormone on thymus physiology. Clinical and Developmental Immunology. 1998;6(3-4):317-23.

[206] Savino W, Postel-Vinay M, Smaniotto S, Dardenne M. The thymus gland: A target organ for growth hormone. Scandinavian Journal of Immunology. 2002;55(5):442-52.

[207] Bartz S, Mody A, Hornik C, Bain J, Muehlbauer M, Kiyimba $\mathrm{T}$, et al. Severe acute malnutrition in childhood: Hormonal and metabolic status at presentation, response to treatment, and predictors of mortality. The Journal of Clinical Endocrinology \& Metabolism. 2014;99(6): 2128-37.

[208] Hansen BR, Kolte L, Haugaard SB, Dirksen C, Jensen FK, Ryder LP, et al. Improved thymic index, density and output in HIV-infected patients following low-dose growth hormone therapy: A placebo controlled study. Aids. 2009;23(16):2123-31.

[209] Barone KS, O'Brien PC, Stevenson JR. Characterization and mechanisms of thymic atrophy in protein-malnourished mice: Role of corticosterone. Cellular Immunology. 1993;148(1):226-33.

[210] Haeryfar S, Berczi I. The thymus and the acute phase response. Cellular and Molecular Biology (Noisy-le-Grand, France). 2001;47(1):145-56.

[211] Golden MN, Jackson A, Golden B. Effect of zinc on thymus of recently malnourished children. The Lancet. 1977;310(8047):1057-9.

[212] Chevalier P. Zinc and duration of treatment of severe malnutrition. The Lancet. 1995;345(8956):1046-7.

[213] Cobbold SP. The mTOR pathway and integrating immune regulation. Immunology. 2013;140(4):391-8.

[214] Peter C, Waldmann H, Cobbold SP. mTOR signalling and metabolic regulation of $\mathrm{T}$ cell differentiation. Current Opinion in Immunology. 2010;22(5):655-61.

[215] Monk JM, Steevels TA, Hillyer LM, Woodward B. Constitutive, but not challenge-induced, interleukin-10 production is robust in acute pre-pubescent protein and energy deficits: New support for the tolerance hypothesis of malnutrition-associated immune depression based on cytokine production in vivo. International Journal of Environmental Research and Public Health. 2011;8(1): 117-35.

[216] Shepherd A. Nutrition through the life span. Part 3: Adults aged 65 years and over. British Journal of Nursing. 2009;18(5)

[217] Shepherd AA. Nutrition through the life-span. Part 2: Children, adolescents and adults. British Journal of Nursing. 2008;17(21).

[218] Shepherd AA. Nutrition through the life-span. Part 1: Preconception, pregnancy and infancy. British Journal of Nursing. 2008;17(20).

[219] Roseboom T, de Rooij S, Painter R. The Dutch famine and its long-term consequences for adult health. Early Human Development. 2006;82(8):485-91.

[220] Stein Z, Susser M, Saenger G, Marolla F. Famine and human development: The Dutch Hunger Winter of 1944-1945. 1975.

[221] Stein Z, Susser M, Saenger G, Marolla F. Nutrition and mental performance. Science. 1972;178(4062):708-13.

[222] Clarkston W, Pantano M, Morley J, Horowitz M, Littlefield J, Burton F. Evidence for the anorexia of aging: Gastrointestinal transit and hunger in healthy elderly vs. young adults. American Journal of PhysiologyRegulatory, Integrative and Comparative Physiology. 1997;272(1):R243-R8.

[223] Cook CG, Andrews JM, Jones KL, Wittert GA, Chapman I, Morley JE, et al. Effects of small intestinal nutrient infusion on appetite and pyloric motility are modified by age. American Journal of Physiology-Regulatory, Integrative and Comparative Physiology. 1997;273(2):R755-R61.

[224] Moriguti JC, Das SK, Saltzman E, Corrales A, McCrory MA, Greenberg AS, et al. Effects of a 6-week hypocaloric diet on changes in body composition, hunger, and subsequent weight regain in healthy young and older adults. The Journals of Gerontology Series A: Biological Sciences and Medical Sciences. 2000;55(12):B580-B7.

[225] Morley JE. Anorexia of aging: Physiologic and pathologic. The American Journal of Clinical Nutrition. 1997;66(4):760-73.

[226] Holloszy JO, Roberts SB. Effects of aging on energy requirements and the control of food intake in men. The Journals of Gerontology Series A: Biological Sciences and Medical Sciences. 1995;50(Special_Issue):101-6.

[227] Rolls BJ, Dimeo KA, Shide DJ. Age-related impairments in the regulation of food intake. The American Journal of Clinical Nutrition. 1995;62(5):923-31.

[228] Black A, Cole T. Within-and between-subject variation in energy expenditure measured by the doubly-labelled water technique: Implications for validating reported dietary energy intake. European Journal of Clinical Nutrition. 2000;54(5):386.

[229] Goran MI, Beer WH, Wolfe RR, Poehlman ET, Young VR. Variation in total energy expenditure in young healthy freeliving men. Metabolism. 1993;42(4):487-96.

[230] Boghossian S, Veyrat-Durebex C, Alliot J. Age-related changes in adaptive macronutrient intake in swimming male and female Lou rats. Physiology \& Behavior. 2000;69(3):231-8.

[231] Das SK, Moriguti JC, McCrory MA, Saltzman E, Mosunic C, Greenberg AS, et al. An underfeeding study in healthy men and women provides further evidence of impaired reg- 
ulation of energy expenditure in old age. The Journal of Nutrition. 2001;131(6):1833-8.

[232] Gruenewald DA, Naai MA, Marck BT, Matsumoto AM. Age-related decrease in neuropeptide-Y gene expression in the arcuate nucleus of the male rat brain is independent of testicular feedback. Endocrinology. 1994;134(6):2383-9.

[233] Kaneda T, Makino S, Nishiyama M, Asaba K, Hashimoto K. Differential neuropeptide responses to starvation with ageing. Journal of Neuroendocrinology. 2001;13(12): 1066-75.

[234] Kumar MV, Moore RL, Scarpace PJ. $\beta 3$-Adrenergic regulation of leptin, food intake, and adiposity is impaired with age. Pflügers Archiv. 1999;438(5):681-8.

[235] Li H, Matheny M, Tümer N, Scarpace PJ. Aging and fasting regulation of leptin and hypothalamic neuropeptide $\mathrm{Y}$ gene expression. American Journal of PhysiologyEndocrinology And Metabolism. 1998;275(3):E405-E11.

[236] Veyrat-Durebex C, Alliot J. Changes in pattern of macronutrient intake during aging in male and female rats. Physiology \& Behavior. 1997;62(6):1273-8.

[237] Wolden-Hanson T, Marck BT, Matsumoto AM. Blunted hypothalamic neuropeptide gene expression in response to fasting, but preservation of feeding responses to AgRP in aging male Brown Norway rats. American Journal of Physiology-Regulatory, Integrative and Comparative Physiology. 2004;287(1):R138-R46.

[238] Wolden-Hanson T, Marck BT, Matsumoto AM. Troglitazone treatment of aging Brown Norway rats improves food intake and weight gain after fasting without increasing hypothalamic NPY gene expression. Experimental Gerontology. 2002;37(5):679-91.

[239] Blanton CA, Horwitz BA, McDonald RB. Neurochemical Alterations During Age-Related Anorexia. Proceedings of the Society for Experimental Biology and Medicine. 1999;221(3):153-65.

[240] Blundell JE. Understanding anorexia in the elderly: Formulating biopsychological research strategies. Neurobiology of Aging. 1988;9:18-20.

[241] Horwitz BA, Blanton CA, McDonald RB. Physiologic determinants of the anorexia of aging: Insights from animal studies. Annual Review of Nutrition. 2002;22(1):417-38.

[242] Roberts S, Hays N. Regulation of energy intake in old age. Functional Neurobiology of Aging, edited by Hof PR and Mobbs CV San Diego, CA: Academic. 2001:829-38.

[243] Stunkard AJ, Messick S. The three-factor eating questionnaire to measure dietary restraint, disinhibition and hunger. Journal of Psychosomatic Research. 1985;29(1):71-83.

[244] Hays NP, Bathalon GP, Roubenoff R, McCrory MA, Roberts SB. Eating behavior and weight change in healthy postmenopausal women: Results of a 4-year longitudinal study. The Journals of Gerontology Series A: Biological Sciences and Medical Sciences. 2006;61(6):608-15.

[245] Wurtman JJ, Lieberman H, Tsay R, Nader T, Chew B. Calorie and nutrient intakes of elderly and young subjects measured under identical conditions. Journal of Gerontology. 1988;43(6):B174-B80.

[246] Bergmann J, Chassany O, Petit A, Triki R, Caulin C, Segrestaa J. Correlation between echographic gastric emptying and appetite: Influence of psyllium. Gut. 1992;33(8): 1042-3.

[247] Brown EL. Factors influencing food choices and intake. Geriatrics. 1976;31(9):89-92.
[248] Campfield LA, Smith FJ. Blood glucose dynamics and control of meal initiation: A pattern detection and recognition theory. Physiological Reviews. 2003;83(1):25-58.

[249] Melanson KJ, Westerterp-Plantenga MS, Campfield LA, Saris WH. Appetite and blood glucose profiles in humans after glycogen-depleting exercise. Journal of Applied Physiology. 1999;87(3):947-54.

[250] Horowitz M, Jones K, Edelbroek MA, Smout AJ, Read NW. The effect of posture on gastric emptying and intragastric distribution of oil and aqueous meal components and appetite. Gastroenterology. 1993;105(2):382-90.

[251] Sepple C, Read N. Gastrointestinal correlates of the development of hunger in man. Appetite. 1989;13(3): 183-91.

[252] Shafer RB, Levine AS, Marlette JM, Morley JE. Effects of xylitol on gastric emptying and food intake. The American Journal of Clinical Nutrition. 1987;45(4):744-7.

[253] Evans Ma, Triggs Ej, Cheung M, Broe Ga, Creasey H. Gastric emptying rate in the elderly: Implications for drug therapy. Journal of the American Geriatrics Society. 1981;29(5):201-5.

[254] Moore JG, Tweedy C, Christian PE, Datz FL. Effect of age on gastric emptying of liquid-solid meals in man. Digestive Diseases and Sciences. 1983;28(4):340-4.

[255] Van Liere EJ, Northup DW. The emptying time of the stomach of old people. American Journal of Physiology-Legacy Content. 1941;134(4):719-22.

[256] Wegener M, Börsch G, Schaffstein J, Lüth I, Rickels R, Ricken D. Effect of ageing on the gastro-intestinal transit of a lactulose-supplemented mixed solid-liquid meal in humans. Digestion. 1988;39(1):40-6.

[257] Finch CE, Hayflick L. Handbook of the Biology of Aging: Van Nostrand Reinhold Co. 1977.

[258] Roth GS. Hormone action during aging: Alterations and mechanisms. Mechanisms of Ageing and Development. 1979;9(5):497-514.

[259] Geary N. Pancreatic glucagon signals postprandial satiety. Neuroscience \& Biobehavioral Reviews. 1990;14(3):32338.

[260] MacIntosh CG, Andrews JM, Jones KL, Wishart JM, Morris HA, Jansen JB, et al. Effects of age on concentrations of plasma cholecystokinin, glucagon-like peptide 1, and peptide YY and their relation to appetite and pyloric motility. The American Journal of Clinical Nutrition. 1999;69(5):999-1006.

[261] Martinez M, Hernanz A, Gómez-Cerezo J, Peña J, Vazquez $\mathrm{JJ}$, Arnalich F. Alterations in plasma and cerebrospinal fluid levels of neuropeptides in idiopathic senile anorexia. Regulatory Peptides. 1993;49(2):109-17.

[262] Smith GP, Gibbs J. The satiating effects of cholecystokinin and bombesin-like peptides. Satiation: From Gut to Brain, Oxford University Press, New York. 1998:97-125.

[263] Sturm K, MacIntosh CG, Parker BA, Wishart J, Horowitz M, Chapman IM. Appetite, food intake, and plasma concentrations of cholecystokinin, ghrelin, and other gastrointestinal hormones in undernourished older women and well-nourished young and older women. The Journal of Clinical Endocrinology \& Metabolism. 2003;88(8): 3747-55.

[264] Doty RL, Shaman P, Applebaum SL, Giberson R, Siksorski L, Rosenberg L. Smell identification ability: Changes with age. Science. 1984;226:1441-3. 
[265] Finkelstein JA, Schiffman SS. Workshop on taste and smell in the elderly: An overview. Physiology \& Behavior. 1999;66(2):173-6.

[266] Schiffman S. Changes in taste and smell: Drug interactions and food preferences. Nutrition Reviews. 1994;52(8):11-4.

[267] Schiffman S. Food recognition by the elderly. Journal of Gerontology. 1977;32(5):586-92.

[268] Schiffman SS. Taste and smell losses in normal aging and disease. Jama. 1997;278(16):1357-62.

[269] Weiffenbach JM, Baum BJ, Burghauser R. Taste thresholds: Quality specific variation with human aging. Journal of Gerontology. 1982;37(3):372-7.

[270] McCrory MA, Fuss PJ, McCallum JE, Yao M, Vinken AG, Hays NP, et al. Dietary variety within food groups: Association with energy intake and body fatness in men and women. The American Journal of Clinical Nutrition. 1999;69(3):440-7.

[271] McCrory MA, Fuss PJ, Saltzman E, Roberts SB. Dietary determinants of energy intake and weight regulation in healthy adults. The Journal of Nutrition. 2000;130(2): 276S-9S.

[272] Schulz TJ, Zarse K, Voigt A, Urban N, Birringer M, Ristow M. Glucose restriction extends Caenorhabditis elegans life span by inducing mitochondrial respiration and increasing oxidative stress. Cell Metabolism. 2007;6(4): 280-93

[273] Schlotterer A, Kukudov G, Bozorgmehr F, Hutter H, Du $\mathrm{X}$, Oikonomou D, et al. C. elegans as model for the study of high glucose-mediated life span reduction. Diabetes. 2009;58(11):2450-6.

[274] Mortuza R, Chen S, Feng B, Sen S, Chakrabarti S. High glucose induced alteration of SIRTs in endothelial cells causes rapid aging in a p300 and FOXO regulated pathway. PLoS One. 2013;8(1):e54514.

[275] Zhang B, Cui S, Bai X, Zhuo L, Sun X, Hong Q, et al. SIRT3 overexpression antagonizes high glucose accelerated cellular senescence in human diploid fibroblasts via the SIRT3-FOXO1 signaling pathway. Age. 2013;35(6): 2237-53.

[276] Honda Y, Tanaka M, Honda S. Trehalose extends longevity in the nematode Caenorhabditis elegans. Aging Cell. 2010;9(4):558-69.

[277] Mouchiroud L, Molin L, Kasturi P, Triba MN, Dumas $\mathrm{ME}$, Wilson MC, et al. Pyruvate imbalance mediates metabolic reprogramming and mimics lifespan extension by dietary restriction in Caenorhabditis elegans. Aging Cell. 2011;10(1):39-54.

[278] Edwards CB, Copes N, Brito AG, Canfield J, Bradshaw PC. Malate and fumarate extend lifespan in Caenorhabditis elegans. PLoS One. 2013;8(3):e58345.

[279] Denzel MS, Storm NJ, Gutschmidt A, Baddi R, Hinze $\mathrm{Y}$, Jarosch E, et al. Hexosamine pathway metabolites enhance protein quality control and prolong life. Cell. 2014;156(6):1167-78.

[280] Rosedale R, Westman EC, Konhilas JP. Clinical experience of a diet designed to reduce aging. The Journal of Applied Research. 2009;9(4):159.

[281] Aston LM. Glycaemic index and metabolic disease risk. Proceedings of the Nutrition Society. 2006;65(1):125-34.

[282] Barclay AW, Petocz P, McMillan-Price J, Flood VM, Prvan T, Mitchell P, et al. Glycemic index, glycemic load, and chronic disease risk-a meta-analysis of observa- tional studies. The American Journal of Clinical Nutrition. 2008;87(3):627-37.

[283] Allen NE, Appleby PN, Key TJ, Bueno-de-Mesquita H, Ros MM, Kiemeney LA, et al. Macronutrient intake and risk of urothelial cell carcinoma in the European prospective investigation into cancer and nutrition. International Journal of Cancer. 2013;132(3):635-44.

[284] Le Couteur DG, Solon-Biet S, Cogger VC, Mitchell SJ, Senior A, de Cabo R, Raubenheimer D, Simpson SJ. The impact of low-protein high-carbohydrate diets on aging and lifespan. Cellular and Molecular Life Sciences. 2016;73(6):1237-52.

[285] Fanson BG, Weldon CW, Pérez-Staples D, Simpson SJ, Taylor PW. Nutrients, not caloric restriction, extend lifespan in Queensland fruit flies (Bactrocera tryoni). Aging Cell. 2009;8(5):514-23.

[286] Carey JR, Harshman LG, Liedo P, Müller HG, Wang JL, Zhang Z. Longevity-fertility trade-offs in the tephritid fruit fly, Anastrepha ludens, across dietary-restriction gradients. Aging Cell. 2008;7(4):470-7.

[287] Min K-J, Tatar M. Restriction of amino acids extends lifespan in Drosophila melanogaster. Mechanisms of Ageing and Development. 2006;127(7):643-6.

[288] Lee KP, Simpson SJ, Clissold FJ, Brooks R, Ballard JWO, Taylor PW, et al. Lifespan and reproduction in Drosophila: New insights from nutritional geometry. Proceedings of the National Academy of Sciences. 2008;105(7):2498-503.

[289] Bruce KD, Hoxha S, Carvalho GB, Yamada R, Wang H-D, Karayan P, et al. High carbohydrate-low protein consumption maximizes Drosophila lifespan. Experimental Gerontology. 2013;48(10):1129-35.

[290] Maklakov AA, Simpson SJ, Zajitschek F, Hall MD, Dessmann J, Clissold F, et al. Sex-specific fitness effects of nutrient intake on reproduction and lifespan. Curr Biol. 2008;18(14):1062-6.

[291] Solon-Biet SM, McMahon AC, Ballard JWO, Ruohonen $\mathrm{K}, \mathrm{Wu} \mathrm{LE}, \mathrm{Cogger} \mathrm{VC}$, et al. The ratio of macronutrients, not caloric intake, dictates cardiometabolic health, aging, and longevity in ad libitum-fed mice. Cell Metabolism. 2014;19(3):418-30.

[292] Park B, Lee J, Kim J. Imbalanced nutrient intake in cancer survivors from the examination from the nationwide health examination center-based cohort. Nutrients. 2018;10(2):212.

[293] Miller RA, Buehner G, Chang Y, Harper JM, Sigler R, Smith-Wheelock M. Methionine-deficient diet extends mouse lifespan, slows immune and lens aging, alters glucose, T4, IGF-I and insulin levels, and increases hepatocyte MIF levels and stress resistance. Aging Cell. 2005;4(3):119-25.

[294] Sun L, Sadighi Akha AA, Miller RA, Harper JM. Life-span extension in mice by preweaning food restriction and by methionine restriction in middle age. Journals of Gerontology Series A: Biomedical Sciences and Medical Sciences. 2009;64(7):711-22.

[295] Schrager MA, Metter EJ, Simonsick E, Ble A, Bandinelli $\mathrm{S}$, Lauretani F, et al. Sarcopenic obesity and inflammation in the InCHIANTI study. Journal of Applied Physiology. 2007;102(3):919-25.

[296] Mensink RP, Zock PL, Kester AD, Katan MB. Effects of dietary fatty acids and carbohydrates on the ratio of serum total to HDL cholesterol and on serum 
lipids and apolipoproteins: A meta-analysis of 60 controlled trials. The American Journal of Clinical Nutrition. 2003;77(5):1146-55.

[297] Summers L, Fielding B, Bradshaw H, Ilic V, Beysen C, Clark M, et al. Substituting dietary saturated fat with polyunsaturated fat changes abdominal fat distribution and improves insulin sensitivity. Diabetologia. 2002;45(3): 369-77.

[298] Appel LJ, Sacks FM, Carey VJ, Obarzanek E, Swain JF, Miller ER, et al. Effects of protein, monounsaturated fat, and carbohydrate intake on blood pressure and serum lipids: Results of the OmniHeart randomized trial. Jama. 2005;294(19):2455-64.

[299] Mozaffarian D, Pischon T, Hankinson SE, Rifai N, Joshipura K, Willett WC, et al. Dietary intake of trans fatty acids and systemic inflammation in women. The American Journal of Clinical Nutrition. 2004;79(4):606-12.

[300] Mozaffarian D, Wilson PW, Kannel WB. Beyond established and novel risk factors. Circulation. 2008;117(23): 3031-8.

[301] Mozaffarian D. Trans fatty acids-Effects on systemic inflammation and endothelial function. Atherosclerosis Supplements. 2006;7(2):29-32.

[302] Pamplona R, Portero-Otin M, Riba D, Ruiz C, Prat J, Bellmunt MJ, et al. Mitochondrial membrane peroxidizability index is inversely related to maximum life span in mammals. Journal of Lipid Research. 1998;39(10):1989-94.

[303] Mitchell TW, Buffenstein R, Hulbert A. Membrane phospholipid composition may contribute to exceptional longevity of the naked mole-rat (Heterocephalus glaber): A comparative study using shotgun lipidomics. Experimental Gerontology. 2007;42(11):1053-62.

[304] Hulbert AJ. Metabolism and longevity: Is there a role for membrane fatty acids? Integrative and Comparative Biology. 2010;50(5):808-17.

[305] Hulbert AJ, Beard LA, Grigg GC. The exceptional longevity of an egg-laying mammal, the short-beaked echidna (Tachyglossus aculeatus) is associated with peroxidation-resistant membrane composition. Experimental Gerontology. 2008;43(8):729-33.

[306] Miquel J, Fleming J, Economos AC. Antioxidants, metabolic rate and aging in Drosophila. Archives of Gerontology and Geriatrics. 1982;1(2):159-65.

[307] Sawada M, Enesco HE. Vitamin E extends lifespan in the short-lived rotifer Asplanchna brightwelli. Experimental Gerontology. 1984;19(3):179-83.

[308] Harrington LA, Harley CB. Effect of vitamin E on lifespan and reproduction in Caenorhabditis elegans. Mechanisms of Ageing and Development. 1988;43(1):71-8.

[309] Navarro A, Gómez C, Sánchez-Pino M-J, González H, Bández MJ, Boveris AD, et al. Vitamin $\mathrm{E}$ at high doses improves survival, neurological performance, and brain mitochondrial function in aging male mice. American Journal of Physiology-Regulatory, Integrative and Comparative Physiology. 2005;289(5):R1392-R9.

[310] Garg S, Mahajan S. Effect of ascorbic acid on longevity, catalase and lipid peroxidation in Callosobruchus maculatus F. Age. 1993;16(3):87-92.

[311] Dallaire A, Garand C, Paquet ER, Mitchell SJ, de Cabo $\mathrm{R}$, Simard MJ, et al. Down regulation of miR-124 in both Werner syndrome DNA helicase mutant mice and mutant Caenorhabditis elegans wrn-1 reveals the importance of this microRNA in accelerated aging. Aging (Albany NY). 2012;4(9):636.

[312] Preuss HG, Echard B, Clouatre D, Bagchi D, Perricone NV. Niacin-bound chromium increases life span in Zucker Fatty Rats. Journal of Inorganic Biochemistry. 2011;105(10):1344-9.

[313] Schmeisser K, Mansfeld J, Kuhlow D, Weimer S, Priebe $\mathrm{S}$, Heiland I, et al. Role of sirtuins in lifespan regulation is linked to methylation of nicotinamide. Nature Chemical Biology. 2013;9(11):693-700.

[314] Lesperance M, Olivotto I, Forde N, Zhao Y, Speers C, Foster $\mathrm{H}$, et al. Mega-dose vitamins and minerals in the treatment of non-metastatic breast cancer: An historical cohort study. Breast Cancer Research and Treatment. 2002;76(2): 137-43.

[315] Hornsby PJ, Harris SE. Oxidative damage to DNA and replicative lifespan in cultured adrenocortical cells. Experimental Cell Research. 1987;168(1):203-17.

[316] Poehlman ET, Melby CL, Badylak SF. Relation of age and physical exercise status on metabolic rate in younger and older healthy men. Journal of Gerontology. 1991;46(2):B54-B8.

[317] Roberts SB, Rosenberg I. Nutrition and aging: Changes in the regulation of energy metabolism with aging. Physiological Reviews. 2006;86(2):651-67.

[318] Keys A, Taylor HL, Grande F. Basal metabolism and age of adult man. Metabolism. 1973;22(4):579-87.

[319] Roberts SB, Dallal GE. Effects of age on energy balance. The American Journal of Clinical Nutrition. 1998;68(4): 975S-9S.

[320] Flatt J. Importance of nutrient balance in body weight regulation. Diabetes/Metabolism Research and Reviews. 1988;4(6):571-81.

[321] Levadoux E, Morio B, Montaurier C, Puissant V, Boirie Y, Fellmann N, et al. Reduced whole-body fat oxidation in women and in the elderly. International Journal of Obesity. 2001;25(1):39.

[322] Stanga Z. Basics in clinical nutrition: Nutrition in the elderly. European e-Journal of Clinical Nutrition and Metabolism. 2009;4(6):e289-99.

[323] Peters A, Schweiger U, Pellerin L, Hubold C, Oltmanns KM, Conrad M, Schultes B, Born J, Fehm HL. The selfish brain: Competition for energy resources. Neuroscience \& Biobehavioral Reviews. 2004;28(2):143-80.

[324] Yamagata AS, Mansur RB, Rizzo LB, Rosenstock T, McIntyre RS, Brietzke E. Selfish brain and selfish immune system interplay: A theoretical framework for metabolic comorbidities of mood disorders. Neuroscience \& Biobehavioral Reviews. 2017;72:43-9.

[325] Alam I, Ng TP, Larbi A. Does inflammation determine whether obesity is metabolically healthy or unhealthy? The aging perspective. Mediators of Inflammation. 2012; 2012.

[326] Alam I, Larbi A, Pawelec G. Nutritional status influences peripheral immune cell phenotypes in healthy men in rural Pakistan. Immunity \& Ageing. 2012;9(1):16.

[327] Alam I, Goldeck D, Larbi A, Pawelec G. Aging affects the proportions of $\mathrm{T}$ and $\mathrm{B}$ cells in a group of elderly men in a developing country-a pilot study from Pakistan. Age. 2013;35(5):1521-30.

[328] Pawelec G. Age and immunity: What is "immunosenescence"? Experimental Gerontology. 2018;105:4-9. 